
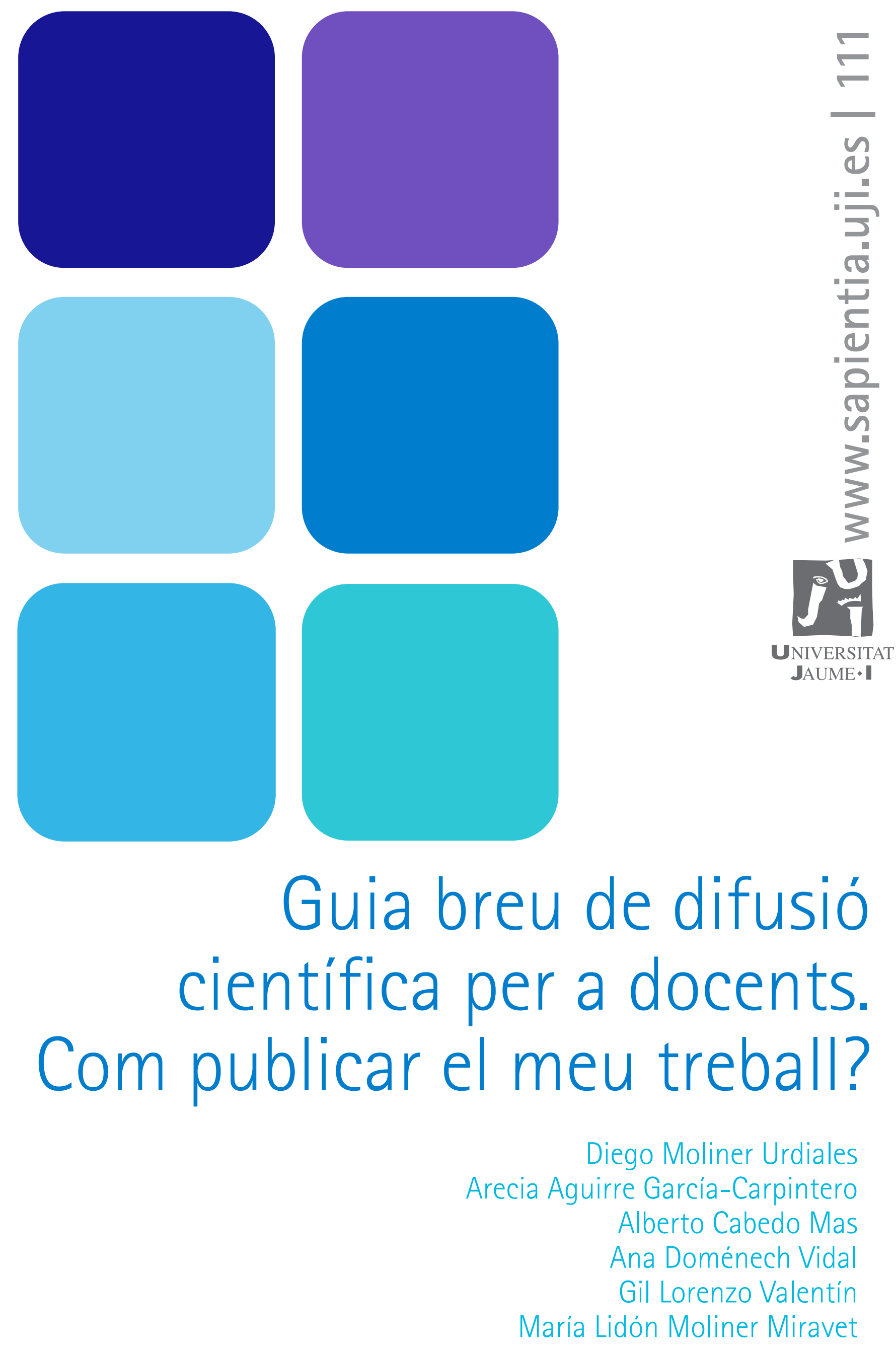


\section{Guia breu de difusió científica per a docents. Com publicar el meu treball?}

Diego Moliner Urdiales

Arecia Aguirre Garcia-Carpintero

Alberto Cabedo Mas

Ana Doménech Vidal

Gil Lorenzo Valentín

María Lidón Moliner Miravet

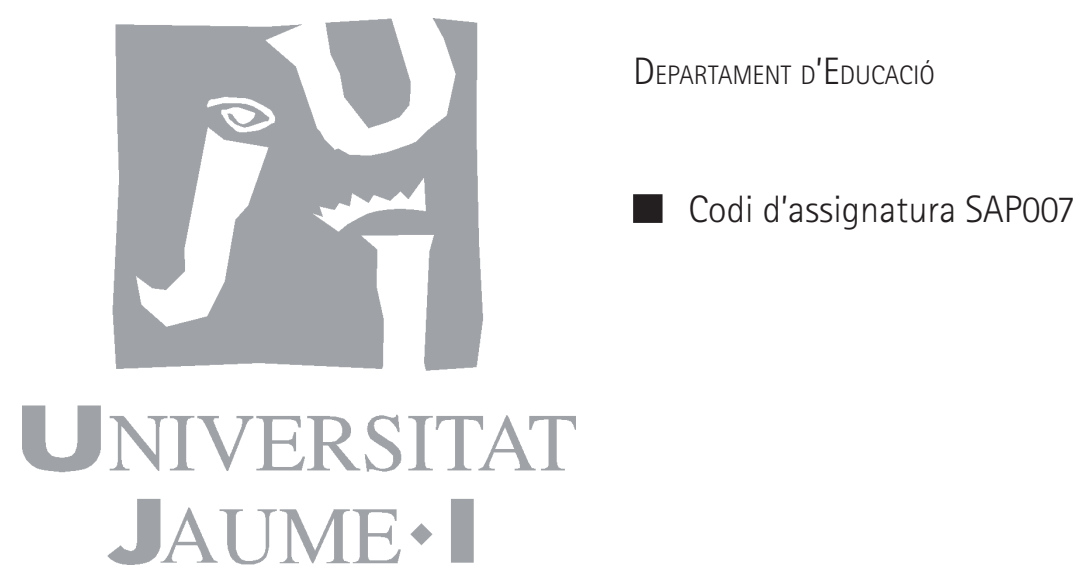


Edita: Publicacions de la Universitat Jaume I. Servei de Comunicació i Publicacions Campus del Riu Sec. Edifici Rectorat i Serveis Centrals. 12071 Castelló de la Plana http://www.tenda.uji.es e-mail: publicacions@uji.es

Col·lecció Sapientia 111

www.sapientia.uji.es

Primera edició, 2016

ISBN: 978-84-16356-52-2

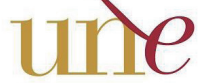
UNión de EDitoRinies
UNIVERSTTARLAS Españolas
Publicacions de la Universitat Jaume I és una editorial membre de l'UNE, cosa que en garanteix la difusió de les obres en els àmbits nacional i internacional. www.une.es

\section{cc) (†) ()}

Reconeixement-CompartirIgual

CC BY-SA

Aquest text està subjecte a una llicència Reconeixement-CompartirIgual de Creative Commons, que permet copiar, distribuir i comunicar públicament l'obra sempre que s'especifique l'autoria i el nom de la publicació fins i tot amb objectius comercials i també permet crear obres derivades, sempre que siguen distribuïdes amb aquesta mateixa llicència. http://creativecommons.org/licenses/by-sa/3.0/legalcode

Aquest llibre, de contingut cientific, ha estat avaluat per persones expertes externes a la Universitat Jaume I, mitjançant el mètode denominat revisió per iguals, doble cec. 


\section{ÍNDEX}

Capítol 1. Què és investigar en educació?

Capítol 2. Per què investigar en educació?

Capítol 3. Com dur a terme una investigació?

Capítol 4. Com accedir a la cerca d'articles científics?

Capítol 5. Com conéixer la qualitat de la literatura científica?

Capítol 6. Com difondre l'informe final d'una investigació?

Capítol 7. Com elaborar un article per a una revista?

Capítol 8. Com elaborar una comunicació per a un congrés?

Bibliografia 


\section{Capitol 1. \\ Què és investigar en educació?}

«La investigació científica és una investigació sistemàtica, controlada, empírica i crítica, de proposicions hipotètiques sobre suposades relacions que existeixen entre fenòmens naturals» (Kerlinger, 1985: 7). Investigar és l'activitat que desenvolupa una persona que es pregunta què és el que ocorre davant un problema, és la curiositat per saber amb profunditat sobre alguna qüestió de manera intencionada. La finalitat última és cercar una resposta a un dubte o problema i així obtenir nous coneixements. Per tal d'investigar s'utilitza el mètode científic, el qual permet explicar els fenòmens que observem. D'aquesta manera, s'obtenen coneixements basats en dades demostrables, repetibles i contrastables.

La necessitat d'investigar en educació i en els centres i institucions educatives sorgeix des del moment en què ens fem preguntes sobre com funcionen les coses, sobre els comportaments de les persones i les institucions educatives (Martínez, 2007). El concepte d'investigació educativa ha anat canviant i adoptant nous significats, alhora que han anat apareixent nous enfocaments i maneres d'entendre el fet educatiu. La investigació educativa és una disciplina que tracta les qüestions i els problemes relatius a la naturalesa, l'epistemologia, la metodologia, les finalitats i els objectius d'aquest àmbit (Arnal i altres, 1994). Té per objecte analitzar amb rigor i objectivitat una situació educativa mitjançant un procés organitzat i sistemàtic. Per a desenvolupar aquesta tasca s'utilitza el mètode científic, la cerca progressiva de coneixement, mitjançant el qual s'explica la realitat educativa amb l'objectiu de millorar la pràctica i les institucions educatives. Des d'una concepció ampla, Hernández Pina (1995) la defineix com l'estudi dels mètodes, els procediments i les tècniques utilitzades per a obtenir un coneixement, una explicació i una comprensió científica dels fenòmens educatius, així com també per a solucionar problemes educatius i socials. Aleshores, qualsevol definició d'aquest terme ha de tindre en compte el fenomen o camp d'estudi, els mètodes, els procediments i les tècniques i el propòsit que es desitja resoldre (Buendía, Colás i Hernández, 1998).

A més, es poden abordar i investigar múltiples temàtiques: un subjecte o grup de subjectes, un mètode, un programa, un recurs o una institució educativa, entre d'altres. La investigació ajuda a proposar noves solucions i a millorar la pràctica educativa. Els fenòmens educatius són altament complexos perquè són diversos i canviants. El caràcter intern i multidisciplinari dels fenòmens educatius fa necessari que el seu estudi es desenvolupe dins de diferents disciplines com la pedagogia, la psicologia, la sociologia o fins i tot l'economia. Així doncs, la investigació educativa posseeix unes particularitats, una varietat d'objectius i una pluralitat de mètodes 
que es veuran més endavant i que fan que en siga complexa la descripció i estudi donat el caràcter dinàmic, interactiu i canviant de la realitat educativa. Però la finalitat última és la millora d'aquelles realitats i pràctiques educatives.

El que sembla estar clar és que la investigació educativa té molts beneficis a diferents nivells, oferint així un coneixement sistematitzat basat en evidències demostrables sobre els fenòmens que s'utilitzen com a base de la presa de decisions en la pràctica docent $i$ en la política educativa. En aquest sentit, es considera vital que aquest coneixement es difonga perquè arribe a la comunitat científica i aquesta es beneficie del nou coneixement generat. 


\section{Capitol 2. \\ Per què investigar \\ en educació?}

La societat del coneixement i de la informació comporta una cultura sustentada pels processos de globalització que impliquen, entre altres, l'adquisició i assimilació de nous coneixements, noves formes de veure el món, l'ús de nous instruments i llenguatges. Exigeix, per tant, grans esforços i competències que faciliten l'adaptació a aquest panorama tan complex i canviant (Castells, 1996). Davant els canvis accelerats de coneixement es requereixen professionals que donen resposta a possibles problemes educatius que puguen existir en la realitat, adoptant una actitud compromesa, reflexiva i crítica.

En termes generals i com ja s'ha esmentat anteriorment, la investigació educativa resulta necessària perquè és l'element que permet transformar, renovar i millorar les pràctiques educatives. És una activitat necessària per a promoure canvis eficaços en les pràctiques educatives que donen resposta a la societat en la qual vivim. Aquests canvis poden estar centrats en el procés d'ensenyament-aprenentatge, en l'organització dels centres, en la convivència i resolució de conflictes o en les relacions interpersonals entre els agents de la comunitat educativa. En resum, es pot dir que els objectius de la investigació serien els següents (Martínez, 2007): donar resposta a la necessitat de conéixer i millorar una determinada realitat educativa; innovar en educació i analitzar els resultats i l'eficàcia d'aquestes innovacions per tal d'avançar en la millora dels resultats educatius; valorar el grau en què s'aconsegueixen determinats objectius educatius; formular judicis de valor sobre la situació estudiada (avaluació); establir les causes que incideixen sobre ella (diagnòstic). Açò facilita poder intervindre per a potenciar, modificar i millorar les situacions educatives.

El professorat necessita recursos, formació i estratègies que permeten trobar respostes realistes que li possibiliten adaptar-se a aquesta societat complexa $i$ en un constant canvi. La investigació s'erigeix com un dels mecanismes que faciliten identificar aquestes necessitats i efectuar diagnòstics precisos per a la presa de decisions en l'àmbit educatiu. Per tant, implica el compromís de l'investigador en la cerca de solucions i recursos per a generar canvis eficaços que milloren les actuacions educatives. Tot açò fa que es puga afirmar que investigar en educació significa millorar la qualitat educativa. 


\section{Capitol 3. \\ Com dur a terme \\ una investigació?}

Abans de presentar quines són les fases del mètode científic, que permeten investigar en les àrees educatives, sempre s'han de tenir en compte una sèrie de qüestions a l'hora d'abordar una investigació (Ponce de León i Lago, 2014).

- És fonamental que el tema que s'escull per a centrar la investigació siga de l'interés de l'investigador. S'ha de tindre present que es tractarà d'una àrea de coneixement en la qual la persona que investiga ha de tindre una formació acadèmica. Únicament d'aquesta manera es podrà dur a terme una investigació rigorosa i honesta.

- Sempre s'ha de ser rigorós amb els límits i l'estructuració de la pròpia investigació. No es poden abastar temes massa amplis o generals. És recomanable indagar en una petita qüestió i explorar-la a fons.

- El tema escollit ha se ser sempre inèdit.

- S'ha de dissenyar una proposta que destaque els elements més importants de la investigació, centrar les idees i permetre un plantejament seriós de la idea que es vol estudiar. Una vegada que la proposta estiga dissenyada, és important trobar un director/a que la recolze i desitge acompanyar el procés.

- És de gran ajuda definir uns objectius que marquen el repte que proposa la investigació.

- Tota investigació ha de partir d'un marc teòric. Abans de començar a realitzar qualsevol fase d'investigació, s'ha de saber si existeix literatura científica sobre aquest tema, així com també les fonts on trobar la informació.

- S'ha de decidir si es tractarà d'un projecte:

- Teòric: d'investigació documental.

- Pràctic: d'investigació en el camp.

- Mixt: que combina ambdues possibilitats.

En la següent taula s'han sistematitzat les diferents fases del mètode científic que es desenvolupen en els següents paràgrafs: 
Taula 1. Fases del mètode científic

\begin{tabular}{|c|c|l|l|l|l|}
\hline \multicolumn{1}{|c|}{ Fase 1 } & \multicolumn{1}{c|}{ Fase 2 } & \multicolumn{1}{c|}{ Fase 3 } & Fase 4 & \multicolumn{1}{c|}{ Fase 5 } & \multicolumn{1}{c|}{ Fase 6 } \\
\hline $\begin{array}{l}\text { Selecció d'un } \\
\text { tema o àrea a } \\
\text { investigar }\end{array}$ & $\begin{array}{l}\text { Identificació } \\
\text { d'un proble- } \\
\text { ma }\end{array}$ & $\begin{array}{l}\text { Revisió de } \\
\text { la literatura } \\
\text { científica }\end{array}$ & $\begin{array}{l}\text { Disseny i } \\
\text { presa de } \\
\text { dades }\end{array}$ & $\begin{array}{l}\text { Anàlisi de } \\
\text { dades }\end{array}$ & $\begin{array}{l}\text { Redacció de } \\
\text { l'informe } \\
\text { final }\end{array}$ \\
\hline
\end{tabular}

Font: Sabariego i Bisquerra (2004)

1. Selecció d'un tema o una àrea a investigar. El tema que es planteja per a iniciar una investigació ha de tindre rellevància social, valor teòric, utilitat metodològica i implicacions pràctiques (Hernández i altres, 2003). Així mateix, ha de ser un tema que ens interesse i ens suscite curiositat. S'ha de plantejar amb exactitud el problema i definir les hipòtesis o preguntes que ens fem.

Per a delimitar el tema d'estudi escollit podem recolzar-nos en les següents preguntes: què vull investigar?; per què vull investigar aquest tema?; qui o què és el subjecte de la meua investigació?; com seleccione qui o què és susceptible de formar part de la mostra i qui o què no ho és?

2. Identificació d'un problema. S'ha de trobar un problema real del qual, o bé se'n desconeix la resposta, o bé es vol validar una creença preestablerta que no haja estat mai testada. En aquest apartat és important examinar l'àmbit d'estudi i expressar amb la major exactitud possible què s'estudiarà, quins objectius es pretenen aconseguir amb la investigació, com es vol dur a terme, amb qui es realitzarà, quina informació cal recollir i com pretenem estudiar-la. Per açò, Sabariego i Bisquerra (2004) exposen que la descripció haurà d'incloure aquestes tres parts: l'objectiu de la investigació, les relacions entre variables o indicadors a estudiar i els subjectes de la investigació. Algunes de les preguntes que ens podem formular en aquesta fase són: què vull aconseguir?; quan faré la investigació?; on la desenvoluparé?; com vull fer-la?; quina informació em resultarà útil?

3. Revisió de la literatura cientifica. Un dels aspectes més rellevants és cercar fonts documentals per a recopilar informació científica d'interés o literatura relacionada amb el problema d'investigació plantejat. Segons Sabariego i Bisquerra (2004), quan parlem de cercar literatura científica ens referim a l'anàlisi de teories, investigacions $i$ antecedents en general que donen validesa al nostre estudi. D'aquesta manera, es determinarà quin és l'estat de la qüestió del problema objecte d'estudi i, si ja està resolt, se n'haurà de plantejar un de nou i començar tot el procés. En definitiva, per a desenvolupar la tercera part de la investigació que es porta a terme, l'investigador ha de fer-se una idea d'aquesta $i$ de les experiències i altres estudis que fins a l'actualitat s'han dut a terme en relació al tema objecte d'investigació.

Per a poder realitzar aquesta qüestió ens podem recolzar en les següents preguntes: què sabem sobre el nostre tema?; què volem saber?; què han dit 
sobre aquest tema -o temes propers-altres autors?; quins aspectes han estat analitzats?; quines conclusions o resultats ja han estat obtinguts?; quines discussions o polèmiques s'han suscitat?; quines experiències s'han dut a terme en relació al tema?

La detecció de la bibliografia o dels documents es vehicula a través de diferents fonts d'informació. Aquestes fan referència a tots els documents que difonen coneixements propis d'una àrea. Danke (1989), en el seu estudi, assenyalava tres fonts d'informació de les quals en destaquem dues:

a) Fonts primàries. Ens proporcionen informació original, testimonis i evidències directes sobre el tema d'investigació. Aquesta documentació és publicada per primera vegada, ja que no ha estat interpretada ni avaluada amb anterioritat. Exemples de fonts primàries són: 1libres específics, monografies, tesis doctorals, capítols de llibres, articles de premsa, articles de revistes especialitzades, ponències, fòrums, vídeos, documentals, comunicacions, documents oficials, pàgines d'internet, etc.

b) Fonts secundàries. Parteixen de conclusions basades en fonts primàries. Aquestes fonts no aporten un coneixement exclusiu, per la qual cosa es basen en informacions que provenen de les fonts primàries. Les fonts secundàries presenten dades o informacions d'altres autors que són reelaborades, interpretades i analitzades. Alguns exemples són: sumaris electrònics, índex de revistes especialitzades, metanàlisi, bases de dades (ERIC, EUDISED, CORDIS, TESEU, CERUK, REDUC), etc.

4. Disseny i presa de dades. La primera de les parts que hem de tindre en compte a l'hora de dissenyar una investigació és conéixer el seu context. Hem de descriure l'escenari d'investigació, la relació de l'investigador amb aquest, l'accés al camp i les situacions que pretenem observar. A continuació, és necessari exposar el mètode d'investigació que s'utilitzarà amb els períodes de temps pertinents, la presentació dels participants, el rol de l'investigador i els participants, les tècniques que seleccionarem i la seua justificació, com durem a terme el registre de les dades $i$, per últim, com realitzarem l'anàlisi. Per a la planificació de la recollida de les dades utilitzem una sèrie de tècniques que són diferents en funció del paradigma de la investigació (quantitatiu o qualitatiu) escollit.

En la següent taula, obtinguda a partir de la dissenyada per Díaz (2010), assenyalem les principals característiques de les investigacions quantitatives i qualitatives: 
Taula 2. Característiques de la investigació quantitativa i qualitativa

\begin{tabular}{|l|l|}
\hline \multicolumn{1}{|c|}{ Investigació quantitativa } & \multicolumn{1}{c|}{ Investigació qualitativa } \\
\hline $\begin{array}{l}\text { Recull informació empírica i objectiva } \\
\text { (aspectes que es poden explicar, contro- } \\
\text { lar, verificar, predir o mesurar) que per la } \\
\text { seua naturalesa sempre aporta xifres com } \\
\text { a resultat. }\end{array}$ & $\begin{array}{l}\text { Recull informació de caràcter subjectiu. } \\
\text { És exploratòria, inductiva i descriptiva. } \\
\text { Les dades adquireixen forma de paraules } \\
\text { i gràfics, més que de nombres. Els seus } \\
\text { resultats es tradueixen en apreciacions } \\
\text { conceptuals per a comprendre i interpretar } \\
\text { la realitat investigada. }\end{array}$ \\
\hline $\begin{array}{l}\text { El seu disseny inclou la formulació d'hi- } \\
\text { pòtesis, que es tradueixen en variables, } \\
\text { amb base en el mesurament numèric i } \\
\text { l'anàlisi estadístic. }\end{array}$ & $\begin{array}{l}\text { El seu disseny no sol incloure hipòtesis, } \\
\text { sinó que parteix d'interrogants. Es carac- } \\
\text { teritza per una interacció subjecte-investi- } \\
\text { gador a través d'entrevistes, observacions, } \\
\text { enregistraments en vídeo, etc., per a } \\
\text { posteriorment convertir la informació en } \\
\text { categories d'anàlisis. }\end{array}$ \\
\hline
\end{tabular}

Font: Díaz (2010: 136)

5. Anàlisi de dades. En aquesta fase de la investigació científica es dóna sentit a la informació obtinguda; es tracta i s'organitza per a poder explicar, descriure i interpretar l'objecte d'estudi i donar resposta al problema plantejat (Sabariego i Bisquerra, 2004). Segons l'enfocament de la investigació, l'anàlisi de dades es portarà endavant d'una manera o d'una altra. En el cas de la investigació de caire quantitatiu, s'apliquen uns mètodes estadístics sobre les bases de dades generades. D'altra banda, si s'opta per investigacions qualitatives, es tendeix a classificar les dades en categories o unitats de significat que tenen la finalitat de sintetitzar i organitzar la informació. En definitiva, en aquest apartat s'han d'interpretar els resultats obtinguts de la presa de dades i elaborar les pròpies conclusions.

6. Redacció de l'informe final. S'elabora l'informe final per tal d'acabar el procés d'investigació i així deixar per escrit els resultats obtinguts amb la metodologia utilitzada, els fonaments teòrics i les conclusions a les quals s'ha arribat. Un bon informe no és el resultat de la improvisació i de l'espontaneïtat, sinó d'un procediment organitzat i planificat. Aquesta última fase és necessària perquè els resultats de la investigació, els coneixements i les troballes es facen públics, de manera que arriben a un públic més ampli que es puga aprofitar de la informació obtinguda. 


\section{Capítol 4. \\ Com accedir \\ a la cerca d'articles científics?}

Tota investigació requereix d'una profunda i rigorosa revisió de la literatura científica. Per tal d'accedir a tota aquesta informació és convenient realitzar una cerca en les diferents bases de dades. En elles podem trobar tant resums com articles complets que serveixen com a base científica per a la investigació que es porta a terme. Una base de dades és una col·lecció d'informació organitzada a la qual es pot accedir fàcilment des de qualsevol ordinador, ja que la majoria de les bases de dades estan en format digital.

En el cas de la Universitat Jaume I, existeixen certes llicències per a algunes de les bases de dades més reconegudes, i qualsevol membre de la seua comunitat educativa (prèvia autenticació) podrà accedir a una major quantitat d'articles i textos complets.

Des de la pàgina de la mateixa universitat, a través de l'adreça $<$ http://ujiapps.uji. es/serveis/cd/bib/recursos/bd/>, es pot accedir a les bases de dades més conegudes en el camp de la investigació educativa:

- Bases de dades del CSIC: ISOC

- Dialnet

- Eric

- PsycNet

- Scopus

- Cercador de revistes UJI

- Latindex

- Web of Science

A continuació es troben explicades de manera detallada cadascuna d'aquestes bases de dades. 
Nom: Base de dades del Csic: IsOc.

Breu descripció: base de dades bibliogràfica que conté les referències dels articles apareguts en les revistes espanyoles des del 1975. El CsIC conté les següents bases de dades produïdes pel Consell Superior de Recerques Científiques:

ISOC: inclou les revistes espanyoles especialitzades en ciències humanes i socials.

ICYT: inclou les revistes espanyoles especialitzades en ciències experimentals.

IME: inclou les revistes espanyoles especialitzades en medicina.

Els elements d'informació de cada document s'estructuren en set camps recuperables: autor, institució on treballa l'autor, títol de l'article, revista (data de publicació, ISSN, localització del document, tipus del document i mode informatiu, classificació temàtica, nombre de referències bibliogràfiques), notes i descriptors.

Adreça web: http://bddoc.csic.es:8085/

Accés: lliure per a qualsevol usuari de l'us.

Temàtica de les publicacions: multidisciplinària: ciències de l'educació, psicologia, sociologia, economia, ciències polítiques, urbanisme, documentació científica, administració pública, dret, història, geografia, filologia, literatura, arqueologia, filosofia, religió i belles arts.

Període: des del 1971.

Llengua de consulta: castellà.

Nom: Dialnet.

Breu descripció: portal bibliogràfic que recopila i facilita l'accés als articles de revistes, tesis doctorals, llibres, etc. Proporciona, quan és possible, l'accés al text complet del document.

Adreça web: http://dialnet.unirioja.es/

Accés: lliure per a qualsevol usuari de l'uJI.

Temàtica de les publicacions: multidisciplinària.

Període: des del 2001.

Llengües de consulta: català, alemany, anglés, castellà, basc, francés, gallec, italià, portugués i romanés. 
Nom: ERIC.

Breu descripció: la base de dades ERIC (Educational Resources Information Center) és patrocinada pel Departament d'Educació d'Estats Units i és la principal font d'informació bibliogràfica referencial en ciències de l'educació, amb cites de més d'1,2 milions de registres. Està conformada per dues fonts: Current Index to Journals in Education (CIJE) i Resources in Education (RIE), que junts cobreixen més de 14.000 documents i indexen sobre 20.000 articles de revistes per any. Addicionalment, ERIC dona cobertura a llibres, conferències, documents governamentals, tesis, mitjans audiovisuals, bibliografies i monografies.

Adreça web: http://www.eric.ed.gov/

Accés: lliure per a qualsevol usuari de l'uJI.

Temàtica de les publicacions: educació.

Període: des del 1966.

Llengua de consulta: anglés.

Nom: PsycNet.

Breu descripció: base de dades de l'American Psychological Association (APA), amb més d'1,5 milions de registres. Cobreix literatura acadèmica $i$ d'investigació i pràctica sobre psicologia, procedents de més de 45 països en més de 30 idiomes. Indexa materials rellevants en disciplines relacionades com ara la medicina, el treball social, la legislació, la criminologia, les ciències socials, i els comportaments en les organitzacions. Adjunta també revistes professionals, tesis, capítols de monografies i monografies, informes tècnics, etc. És una font d'informació imprescindible per als investigadors, professionals i estudiants de psicologia.

Adreça web: http://psycnet.apa.org/

Accés: lliure per a qualsevol usuari de l'usI.

Temàtica de les publicacions: multidisciplinària, tot $\mathrm{i}$ que hi predomina la psicologia.

Període: des del 1806.

Llengua de consulta: anglés. 
Nom: Scopus.

Breu descripció: Scopus és una base de dades europea que naix el 2006 i que ofereix resums i cites. Inclou més de 180.00 títols de totes les branques de la ciència, de més de 5.000 editors internacionals a tot el món, la qual cosa suposa un nombre major de 43 milions de registres i 23 milions de patents de 5 oficines de patents de tot el món.

És destacable la presència de revistes de l'àrea de ciències socials i humanitats, amb més de 5.300 títols. Scopus ofereix la producció científica universal, amb una major representació de la investigació europea, que suposa el $56 \%$ dels títols.

Adreça web: http://www.scopus.com/

Accés: lliure per a qualsevol usuari de l'Us.

Temàtica de les publicacions: multidisciplinària: agricultura, biologia, química, geologia, economia, negocis, enginyeria, salut, ciències de la vida, matemàtiques, física, psicologia, economia, ciències socials, etc.

Període: articles des del 1960.

Llengua de consulta: anglés.

Nom: Cercador de revistes UJI. SFX: revistes electròniques.

Breu descripció: SFX és un servidor de revistes electròniques útil per a la biblioteca. Dins de SFX es manté una base de dades que descriu la col·lecció de la biblioteca. Permet l'accés a una gran quantitat de títols de revistes electròniques. Aquestes es poden cercar per títol i per matèria.

Adreça web:

http://bs81z6ys5q.search.serialssolutions.com/?L=BS8LZ6YS5Q\&tab= JOURNALS

Accés: lliure per a qualsevol usuari de l'usI.

Temàtica de les publicacions: multidisciplinària.

Llengua de consulta: castellà, català i anglés. 
Nom: Web of Science.

Breu descripció: plataforma de consulta de bases de dades de l'Institute for Scientific Information (ISI), servei en línia d'informació científica subministrat per Thomson Reuters. Facilita l'accés a un conjunt de bases de dades en les quals apareixen cites d'articles de revistes científiques, llibres i altres tipus de material imprès de tots els camps del coneixement acadèmic. Permet accedir a les publicacions prèvies d'una determinada investigació publicades a través de l'accés a les seues referències bibliogràfiques citades, o també a les publicacions que citen un document determinat per a descobrir l'impacte d'un treball científic sobre la investigació actual. Finalment, permet connectar-se al text complet de publicacions primàries i altres recursos $\mathrm{i}$ accedir a ells mitjançant un sistema de cerca basat en paraules clau.

Inclou 3 bases per a cada branca del coneixement: Science Citation Index Expanded, Social Science Citation Index i Art \& Humanities Citation Index. Les revistes indexades en aquestes bases de dades són les anomenades Revistes ISI, és a dir, les revistes acadèmiques i d'investigació més prestigioses a nivell mundial.

Adreça web: https://www.accesowok.fecyt.es/

Accés: lliure per a qualsevol usuari de l'UJI.

Temàtica de les publicacions: multidisciplinària.

Període: a partir del 1900.

Llengua de consulta: anglés.

Existeixen altres bases de dades en educació que també poden ser d'utilitat per a la cerca d'articles i altres publicacions, com ara:

- REDINED (Red de Información Educativa): http://redined.mecd.gob.es/xmlui/ browse?type $=$ journal

- IRESIE (Bases de Datos sobre Educación IISUE, UNAM): http://www.iisue.unam. mx/iresie/

- REDIB (Red Iberoamerica de Innovación y Conocimiento Científico): https:// www.redib.org/ 


\section{Capitol 5. \\ Com conéixer la qualitat de la literatura científica?}

Per a mesurar la repercussió que ha obtingut una revista en la comunitat científica existeix el factor d'impacte (també conegut com a índex d'impacte), un concepte més comú en l'idioma anglés: impact factor. Aquest és el quocient del nombre de cites (observades en altres publicacions) dels articles publicats en eixa revista en els darrers dos anys entre el nombre d'articles publicats en la revista en aquests dos anys. Aquest factor és un instrument que s'utilitza per a comparar revistes i avaluar la importància relativa d'una revista concreta dins d'un mateix camp científic.

Cada any, l'Institut per a la Informació Científica (ISI o Institute for Scientific Information) calcula de nou aquest factor per a aquelles publicacions a les quals dóna seguiment i les inclou en l'informe de cites anomenat Journal Citation Reports (JCR).

Són diferents les eines que mesuren el factor d'impacte. Les més conegudes són: JCR, SCIMAGO, IN-RECS (no funciona en l'actualitat) i DICE.

\subsection{Web of Knowledge: JCR (classificació internacional)}

Publicació anual que ens ofereix una mesura de qualitat científica per tal d'avaluar les revistes acadèmiques que proporciona el Journal Citation Report, producte actualment de l'empresa Thomson Reuters. Ens proporciona dades estadístiques que ens permeten determinar, d'una manera sistemàtica i objectiva, la importància relativa de cada revista en la seua categoria temàtica. Així mateix, ens permet conéixer quines són les publicacions que se citen més ràpidament (índex d'immediatesa) i quines tenen major impacte (factor d'impacte) en la comunitat científica. Es valora especialment en acreditacions de la ANECA (PEP i ACADÈMIA) i en altres processos d'avaluació, pel que és imprescindible la seua consulta per a la majoria dels investigadors. El JCR genera dos índexs: JCR Science Edition i JCR Social Science Edition.

No totes les revistes tenen factor d'impacte JCR, i les que el tenen, no és permanentment. El factor d'impacte d'una revista pot variar d'un any a un altre. 


\subsection{Scimago (classificació internacional)}

Scimago és un indicador que mesura la influència científica de les revistes acadèmiques en funció del nombre de cites que rep una revista i la importància i el prestigi de les revistes d'on provenen aquestes citacions, a través del Scimago Journal Rank Indicator (SJR).

Es publiquen informes que ajuden els usuaris a avaluar la grandària de la producció, l'impacte científic, l'especialització temàtica o les xarxes de col·laboració internacional entre institucions. El rang cronològic abasta des del 2003 fins el 2013 i cada informe analitza un quinquenni. Per a la realització de les classificacions es tenen en compte aquelles institucions que en l'últim any del quinquenni han publicat almenys 100 documents científics de qualsevol tipus (articles, revisions, cartes, conferències, etc.) indexats en la base de dades Scopus. Els informes que publica Scimago són la classificació d'institucions més completes del món que estan dedicades a l'anàlisi dels resultats d'investigació de les organitzacions. El públic a qui es destinen els informes és molt ampli. Abarca des de responsables polítics, directors d'investigacions i investigadors, fins als mitjans de comunicació i el públic en general interessat en conéixer l'acompliment de les institucions d'investigació de tot el món.

Cada any, Scimago publica dos informes d'institucions: el SIR iberoamericà i el SIR global. El primer sol aparéixer al març i considera totes les institucions d'educació superior dels països que componen Iberoamèrica amb almenys un document en l'últim any del quinquenni. El sir global es publica al juliol i té en compte aquelles organitzacions, de qualsevol país, que han publicat almenys 100 documents en l'últim any del quinquenni.

\subsection{Latindex (classificació internacional)}

Latindex és un sistema d'informació sobre revistes d'investigació científica, tècnico-professionals i de divulgació científica i cultural que s'editen en els països d'Amèrica Llatina, el Carib, Espanya i Portugal. La idea de creació de Latindex va sorgir el 1995 en la Universitat Nacional Autònoma de Mèxic (UNAM) i es va convertir en una xarxa de cooperació regional a partir del 1997. L'àmbit és multidisciplinari i la llengua de consulta és el castellà.

Actualment, Latindex ofereix tres bases de dades: 1) directori, amb dades bibliogràfiques i de contacte de totes les revistes registrades, ja siguen publicades en suport paper o electrònic; 2) catàleg, que inclou únicament les revistes -impreses o electròniques- que compleixen els criteris de qualitat editorial dissenyats per Latindex; 3) enllaç a revistes electròniques, que permet l'accés als textos complets en els llocs en què es troben disponibles.

Latindex avalua les revistes en funció del compliment d'uns criteris que estableix per a determinar-ne la qualitat. L'accés és lliure per a qualsevol estudiant de l'UJI. Adreça web: http://www.latindex.unam.mx/ 


\subsection{IN-RECS (classificació nacional)}

És l'Índex d'Impacte de les Revistes Espanyoles de Ciències Socials (1996-2010) i ofereix informació estadística a partir del recompte de les cites bibliogràfiques, amb la finalitat de determinar la difusió, la visibilitat, la rellevància i l'impacte científic de les revistes espanyoles d'aquestes temàtiques, així com també dels autors que hi publiquen i de les institucions que s'hi adscriuen.

IN-RECS permet obtindre les següents informacions:

- Saber quin és l'impacte científic d'una revista, la seua evolució i la seua posició respecte de la resta de revistes de l'especialitat a través de diferents indicadors bibliomètrics, el principal dels quals és l'índex d'impacte.

- Conéixer quines són les publicacions que citen a una revista i quines són les citades per ella, així es fa possible traçar afinitats i relacions científiques, a més de conéixer el mercat editorial.

- Saber quins són els articles més citats d'una especialitat, així com quins són els seus autors, els articles i les revistes que els citen i quins citen ells mateixos.

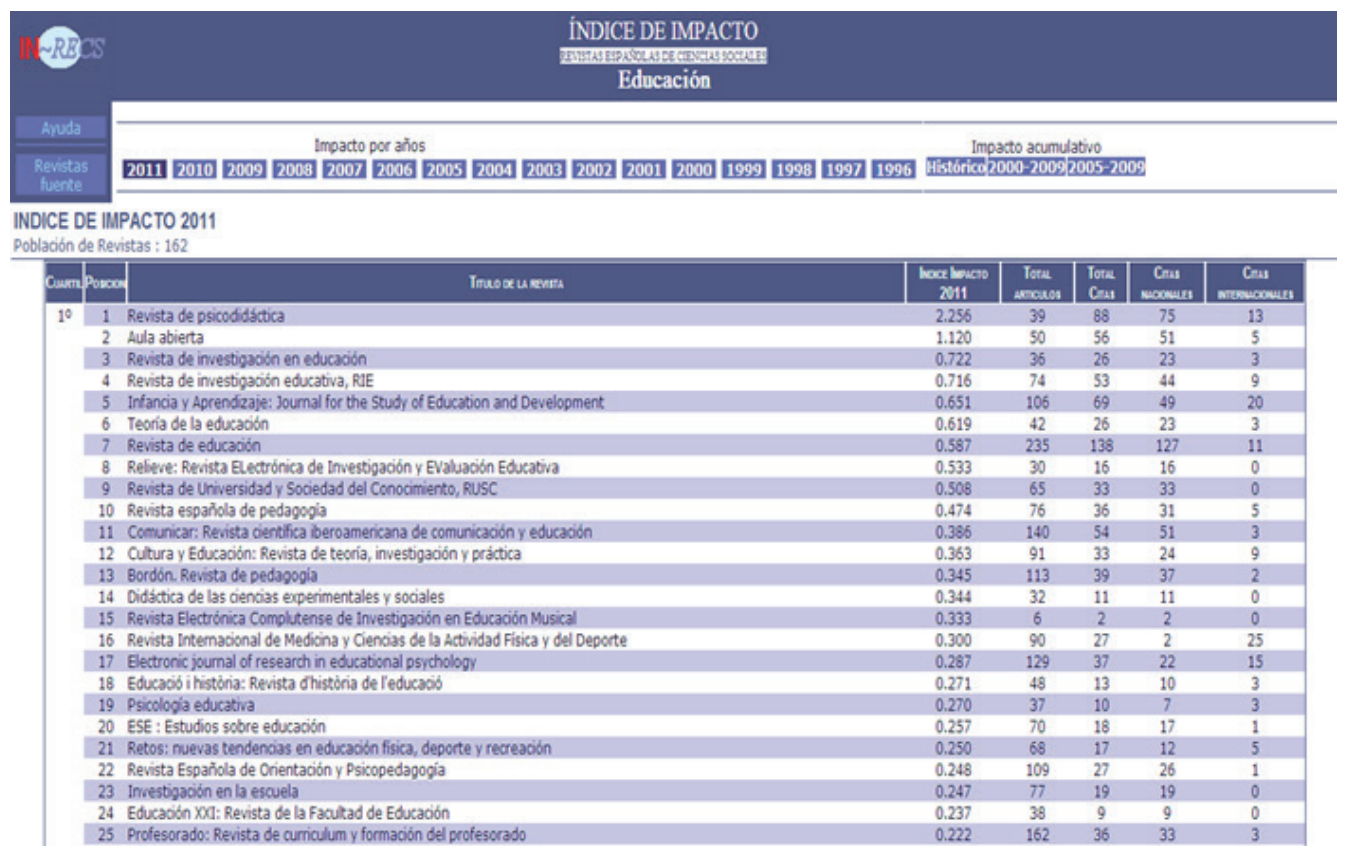

Figura 1. IN-RECS. Font: http://ec3.ugr.es/in-recs/

\subsection{DICE (classificació nacional)}

La Difusió i Qualitat Editorial (DICE) de les revistes espanyoles d'humanitats i ciències socials i jurídiques facilita a l'usuari el coneixement $i$ consulta d'algunes característiques editorials i els indicadors indirectes de qualitat de les revistes espanyoles de ciències socials. 
Aquesta base de dades va aparéixer com a fruit d'un conveni de col·laboració entre el Consell Superior de Recerques Científiques (CSIC) i l'Agència Nacional d'Avaluació de la Qualitat i Acreditació (ANECA). Aquesta última, ANECA, utilitza aquesta base de dades com a referència de qualitat de les publicacions espanyoles en els seus processos d'avaluació del professorat.

Els indicadors de qualitat que DICE ofereix per a les revistes espanyoles d'humanitats i ciències socials s'obtenen directament de les publicacions que rep el Grup de Recerca d'Avaluació de Publicacions Científiques (EPUC). A partir de setembre del 2010, l'avaluació de les publicacions es realitza trimestralment.

Per tal d'actualitzar la informació que es publica en DICE, s'examina l'últim exemplar editat i rebut de cada revista. Hi ha dos indicadors, no obstant, que requereixen de la revisió dels tres últims exemplars editats: obertura exterior dels autors $\mathrm{i}$ internacionalitat de les contribucions.

\subsection{Altres criteris de qualitat de les publicacions}

La mateixa ANECA estableix una sèrie de criteris que han de complir les publicacions científiques i que es consideren indicis de qualitat en el seu camp.

En el camp de les ciències socials, es valoren preferentment les publicacions científiques en revistes de prestigi incloses en llistats com Science Citation Index, Social Sciences Citation Index, Econlit, el catàleg de Latindex o altres llistats generalment admesos en aquest camp. En alguns àmbits relacionats amb l'educació, la Comissió d'Acreditació també utilitza com a referència de qualitat, per a les publicacions espanyoles, la base de dades DICE. 


\section{Capitol 6. \\ Com difondre l'informe final d'una investigació?}

L'últim pas del procés d'investigació correspon a la difusió dels resultats de l'estudi. Açò es duu a terme a través de l'informe final. És fonamental fer pública aquesta informació. Un dels objectius de la investigació és facilitar a altres persones interessades una informació de qualitat sobre les últimes investigacions realitzades. S'assumeix que la divulgació del coneixement és una responsabilitat de qualsevol persona investigadora perquè només així es contribueix al desenvolupament collectiu del coneixement científic.

Per un costat, s'ha de tindre en compte que l'informe final estiga ben estructurat i que seguisca les fases de la investigació. Fem un recordatori de quins són els punts imprescindibles que hi han d'aparéixer:

- Una introducció que resumisca i aproxime el lector a allò que trobarà en l'estudi.

- El marc teòric que procedirà de tota aquella revisió bibliogràfica que s'ha realitzat.

- Un disseny de la investigació en el qual es plasme el problema d'investigació, les preguntes, els objectius, la metodologia utilitzada, les fases de la investigació, el context, la mostra de participants, els instruments i/o estratègies usades, etc.

- L'anàlisi de les dades concretant el procés d'anàlisi i quins n'han estat els resultats.

- Les conclusions obtingudes a partir dels resultats recollits i una discussió teòrica sobre aquests resultats.

- Bibliografia.

D'altra banda, no es pot oblidar que qualsevol informe final ha de reunir tres característiques fonamentals: ser científic, servir d'instrument de comunicació i ser útil (Martínez, 2007).

Un altre aspecte a tindre en compte a l'hora de redactar i organitzar l'informe és que l'estructura del text variarà en funció de la persona a la qual es dirigisca (investigadors, responsables institucionals i polítics, docents, educadors, alumnat, familiars, etc). És per açò que existeixen autors que distingeixen entre diferents tipus d'informes. Entre ells, Martínez (2007) els divideix en: informes científics, orientats a la pràctica i divulgatius. 
Una vegada s'ha escrit l'informe, és el moment de decidir-ne la difusió. Si es parla de la difusió d'un informe científic procedent d'un treball final de grau, màster o una tesi doctoral, el primer que s'haurà de fer és una presentació oficial i pública. Aquesta sol realitzar-se a través d'una exposició oral que pot anar acompanyada d'una presentació visual amb suport informàtic per a aquest fi. Una altra de les presentacions oficials més esteses en aquest tipus de treballs és el pòster científic. En els següents apartats s'analitzarà com es realitza un pòster científic i també una comunicació oral, una informació que ajudarà a planificar i dur a terme la defensa de l'informe final.

\section{Vies de difusió de resultats d'investigació}

Un cop s'ha fet la presentació pública oficial, s'aprecia que aquesta no és suficient per a la vertadera difusió, per això és imprescindible continuar compartint-ne els resultats. Per tal de fer front a aquesta necessitat, calen altres vies de comunicació útils que faciliten la seua difusió. Els dos nivells de difusió es podrien dividir en:

- Oral. A través de diàlegs, comunicacions o pòsters en jornades i congressos, seminaris, xerrades, reunions científiques, etc.

- Escrita. Mitjançant publicacions en revistes científiques especialitzades que després queden registrades en bases de dades d'interés nacional i internacional. Una altra de les opcions escrites que més s'està estenent és la difusió a través de la xarxa d'internet en plataformes lliures, blocs, webs, etc.

D'entre elles, les més comunes en l'àmbit educatiu i de les ciències socials són:

- Congressos. Reunió periòdica nacional o internacional en què es convoquen diferents col·lectius per a debatre qüestions d'actualitat envers una temàtica concreta i compartir experiències referents a aquesta. El comitè organitzatiu de la major part dels congressos publica els treballs que es posen en comú en aquesta jornada a través del llibre d'actes. En ell es poden localitzar les comunicacions i conferències que donen forma a la trobada.

- Revistes. Les revistes contenen articles científics en els quals es poden trobar resultats d'investigacions realitzades entorn d'una disciplina concreta. Les revistes podem trobar-les impreses en paper o publicades a internet.

- Monogràfics. Aquesta modalitat de comunicació és en format lliure. En ells es presenta la totalitat d'una investigació concreta o diferents experiències d'investigació amb una temàtica comuna.

- Audiovisual. A través de vídeos documentals es mostren d'una manera visual quins són els resultats o, fins i tot, el procés d'investigació d'una manera més directa, amena i accessible.

En l'àmbit educatiu, les vies de difusió més generalitzades són les revistes de ciències humanes i socials i els congressos. El format més utilitzat en les revistes és l'article científic. D'entre totes les revistes que existeixen en aquest àmbit, ens centrem en totes aquelles que estan ordenades segons l'índex d'impacte d'INRECS 
i JCR. A més d'aquests dos, que s'expliquen als exemples de les taules següents, es pot tindre en compte també l'índex d'impacte sJR, abans esmentat, atés que cada vegada és un sistema més potent d'avaluació de revistes a nivell internacional, complementari a JCR.

A continuació podem veure alguns exemples d'INRECS i JCR representats en les taules. 
Taula 3. Exemple IN-RECS

\begin{tabular}{|c|c|c|c|c|}
\hline $\begin{array}{l}\text { 1. Revista de psicodidáctica } \\
\text { http://www.ehu.es/ojs/index. } \\
\text { php/psicodidactica }\end{array}$ & 2.256 & $\begin{array}{l}\text { Revista semestral dirigida a docents i investigadors. Es publica en paper des de } \\
\text { l'any } 1996 \text { i començà a editar-se com a revista electrònica l'any } 2010 . \\
\text { En els últims anys, els seus índexs d'impacte la situen en posicions molt des- } \\
\text { tacades, tant en l'àmbit espanyol com en l'internacional. }\end{array}$ & Lliure & $\begin{array}{l}\text { Castellà, basc i } \\
\text { anglés }\end{array}$ \\
\hline $\begin{array}{l}\text { 2. Aula abierta } \\
\text { http://www.elsevier.es/ } \\
\text { es-revista-aula-abierta-389 }\end{array}$ & 1.120 & $\begin{array}{l}\text { Aula abierta va nàixer l'any } 1973 \text { amb l'objectiu de donar cabuda a les publi- } \\
\text { cacions de caràcter educatiu. } \\
\text { La seua periodicitat és semestral. } \\
\text { L'objectiu és publicar aportacions científiques en el camp de la psicologia i de } \\
\text { l'educació. }\end{array}$ & Lliure & $\begin{array}{l}\text { Castellà i } \\
\text { anglés }\end{array}$ \\
\hline $\begin{array}{l}\text { 3. Revista de investigación } \\
\text { en educación } \\
\text { http://webs.uvigo.es/reined/ } \\
\text { ojs/index.php/reined/index }\end{array}$ & 0.722 & $\begin{array}{l}\text { Revista científica semestral editada per la Facultat de Ciències de l'Educació } \\
\text { i de l'Esport de la universitat de Vigo, dedicada a la investigació sobre l'ense- } \\
\text { nyament i l'aprenentatge en els diferents nivells educatius. } \\
\text { Està també disponible el text complet dels últims números. } \\
\text { Aquesta revista està indexada en diferents bases de dades com ara LATINDEX, } \\
\text { ISCOC O DICE. }\end{array}$ & Lliure & $\begin{array}{l}\text { Castellà i } \\
\text { anglés }\end{array}$ \\
\hline
\end{tabular}


Taula 3. Exemple IN-RECS (cont.)

\begin{tabular}{|c|c|c|c|c|}
\hline $\begin{array}{l}\text { 4. Revista de investigación } \\
\text { educativa, RIE } \\
\text { http://revistas.um.es/rie }\end{array}$ & 0.716 & $\begin{array}{l}\text { RIE està patrocinada per AIDIPE (Associació Interuniversitària de Recerca en } \\
\text { Pedagogia), la seu social de la qual està a Barcelona. } \\
\text { AIDIPE també edita, en format electrònic, la Revista Electrònica de Recerca } i \\
\text { Avaluació Educativa, Relleu. } \\
\text { Estan disponibles tots els volums des del número 0, a text complet. }\end{array}$ & Lliure & $\begin{array}{l}\text { Castellà i } \\
\text { anglés }\end{array}$ \\
\hline $\begin{array}{l}\text { 5. Infancia y Aprendizaje: } \\
\text { Journal for the Study of } \\
\text { Education and Development } \\
\text { http://www.fia.es/revistas/ } \\
\text { infanciayaprendizaje/home }\end{array}$ & 0.651 & $\begin{array}{l}\text { Revista internacional de psicologia del desenvolupament i de l'educació que } \\
\text { admet investigació bàsica sobre processos d'aprenentatge i desenvolupament } \\
\text { en l'ésser humà i investigació aplicada i d'intervenció en els àmbits educatius. } \\
\text { Dirigida a investigadors del desenvolupament i de l'educació i a professionals } \\
\text { de l'educació i de la intervenció. } \\
\text { Els treballs publicats inclouen investigacions, revisions i reflexions teòriques. }\end{array}$ & $\begin{array}{l}\text { Alguns } \\
\text { articles } \\
\text { són de } \\
\text { pagament, } \\
\text { altres } \\
\text { gratuiits }\end{array}$ & $\begin{array}{l}\text { Castellà i } \\
\text { anglés }\end{array}$ \\
\hline $\begin{array}{l}\text { 6. Teoría de la educación } \\
\text { http://campus.usal. } \\
\text { es/ teoriadelaeducacion/ }\end{array}$ & 0.619 & $\begin{array}{l}\text { Revista científica fundada el } 1986 \text { que publica treballs originals d'investigació } \\
\text { sobre els aspectes teòrics i pràctics de l'educació. El seu objectiu és aportar } \\
\text { coneixement a investigadors i professionals per a una millor explicació, com- } \\
\text { prensió i optimització de l'acció educativa. } \\
\text { Està consolidada a nivell nacional i internacional i es troba indexada en àmbits } \\
\text { internacionals. } \\
\text { Se n'editen dos números a l'any: al juny i al desembre. }\end{array}$ & Lliure & $\begin{array}{l}\text { Castellà i } \\
\text { anglés }\end{array}$ \\
\hline
\end{tabular}


Taula 3. Exemple IN-RECS (cont.)

\begin{tabular}{|c|c|c|c|c|}
\hline $\begin{array}{l}\text { 7. Revista de educación } \\
\text { http://www.mecd.gob.es/ } \\
\text { revista-de-educacion }\end{array}$ & 0.587 & $\begin{array}{l}\text { Publicació científica del Ministeri d'Educació, Cultura i Esport espanyol. Fun- } \\
\text { dada el } 1940 . \\
\text { Reconegut mitjà de difusió dels avanços en investigació i innovació en aquest } \\
\text { camp, tant des d'una perspectiva nacional com internacional. } \\
\text { Cada any se'n publiquen quatre números amb tres seccions: investigacions, } \\
\text { assajos i ressenyes. }\end{array}$ & Lliure & Castellà \\
\hline $\begin{array}{l}\text { 8. Relieve: Revista } \\
\text { Electrónica de Investiga- } \\
\text { ción y Evaluación Edu- } \\
\text { cativa } \\
\text { http://www.uv.es/relieve/ }\end{array}$ & 0.533 & $\begin{array}{l}\text { Primera revista electrònica d'Espanya, gratuïta i amb una orientació acadèmica. } \\
\text { Aspira a ser un instrument de comunicació per a la comunitat educativa, en } \\
\text { particular en temes d'investigació i avaluació educativa. } \\
\text { Està patrocinada per AIDIPE i s'edita actualment des del departament de Mèto- } \\
\text { des de Recerca i Diagnòstic en Educació (MESURA) de la Facultat de Filosofia i } \\
\text { Ciències de l'Educació de la Universitat de València. }\end{array}$ & Lliure & $\begin{array}{l}\text { Castellà i } \\
\text { anglés }\end{array}$ \\
\hline $\begin{array}{l}\text { 9. Revista de Universidad y } \\
\text { Sociedad del Conocimiento, } \\
\text { RuSC } \\
\text { http://www.uoc.edu/rusc/1/ }\end{array}$ & 0.508 & $\begin{array}{l}\text { Revista electrònica de periodicitat semestral, els números de la qual es confi- } \\
\text { guren al voltant de diversos articles, ressenyes i un dossier monogràfic. } \\
\text { Està impulsada per la Càtedra Unesco d'e-learning de la uoc, que té com a } \\
\text { objectiu la difusió de treballs d'anàlisis i investigació generats principalment } \\
\text { en el marc de les activitats de la càtedra. }\end{array}$ & Lliure & Castellà \\
\hline
\end{tabular}




\begin{tabular}{|c|c|c|c|c|}
\hline $\begin{array}{l}\text { 10. Revista española } \\
\text { de pedagogía } \\
\text { http://revistadepedagogia.org/ }\end{array}$ & 0.474 & $\begin{array}{l}\text { Una de les publicacions més antigues dedicada a la investigació pedagògica. } \\
\text { Ha mantingut sempre uns alts nivells de qualitat, i ha obtingut nombrosos re- } \\
\text { coneixements internacionals. } \\
\text { La revista té caràcter investigador i vocació universal. } \\
\text { És la primera revista en castellà present en el selectiu Social Sciences Citati- } \\
\text { on Index. Està també inclosa en el Journal Citation Reports/Social Sciences } \\
\text { Edition i en el Social Scisearch, així com en SCOPUs, ISOC, LATINDEX, FRANCIS, } \\
\text { etc. }\end{array}$ & $\begin{array}{c}\text { De } \\
\text { pagament. } \\
\text { Subscrip- } \\
\text { ció anual }\end{array}$ & $\begin{array}{l}\text { Castellà i } \\
\text { anglés }\end{array}$ \\
\hline $\begin{array}{l}\text { 11. Comunicar. Revista } \\
\text { científica iberoameri- } \\
\text { cana de comunicación } \\
\text { y educación } \\
\text { http://www.revistacomunicar. } \\
\text { com/ }\end{array}$ & 0.386 & $\begin{array}{l}\text { Revista bilingüe que presenta monogràfics especialitzats en temes de màxima } \\
\text { actualitat disponible a text complet. } \\
\text { Decidida vocació internacional i llatinoamericana amb } 20 \text { anys d'antiguitat i } \\
1.572 \text { articles publicats d'investigacions, experiències, reflexions i propostes. } \\
\text { Està present en } 231 \text { bases de dades internacionals i plataformes d'avaluació. } \\
\text { Compta amb un alt nivell de visibilització i múltiples sistemes de cerca. } \\
\text { Quant a indexacions, el 2013/14, Comunicar és la primera revista en castellà } \\
\text { en JCR (comunicació) i la segona espanyola en JCR (educació). }\end{array}$ & Lliure & $\begin{array}{l}\text { Castellà, } \\
\text { anglés i xinés }\end{array}$ \\
\hline
\end{tabular}




\begin{tabular}{|c|c|c|c|c|}
\hline $\begin{array}{l}\text { 12. Cultura y Educación: } \\
\text { Revista de teoría, inves- } \\
\text { tigación y práctica } \\
\text { http://www.fia.es/revistas/ } \\
\text { culturayeducacion/home }\end{array}$ & 0.363 & $\begin{array}{l}\text { Revista internacional que admet treballs de reflexió, d'investigació educativa } \\
\text { i d'experiències didàctiques degudament avaluades sobre els fenòmens educa- } \\
\text { tius escolars, familiars i socials culturalment situats al llarg de totes les etapes } \\
\text { vitals. } \\
\text { Cultura y Educación va dirigida fonamentalment a investigadors i professio- } \\
\text { nals relacionats amb àmbits educatius i culturals. També a psicòlegs, educa- } \\
\text { dors en diversos àmbits (escola, comunitats, universitats), treballadors socials } \\
\text { i comunitaris. }\end{array}$ & $\begin{array}{l}\text { De } \\
\text { pagament. } \\
\text { Subscrip- } \\
\text { ció anual }\end{array}$ & $\begin{array}{l}\text { Castellà i } \\
\text { anglés }\end{array}$ \\
\hline $\begin{array}{l}\text { 13. Bordón. Revista de } \\
\text { Pedagogía } \\
\text { http://dialnet.unirioja.es/ } \\
\text { servlet/revista?codigo }=236\end{array}$ & 0.345 & $\begin{array}{l}\text { Revista científica pertanyent a l'àmbit de l'educació i editada per la Societat } \\
\text { Espanyola de Pedagogia, fundada el } 1949 \text { i amb un àmbit multidisciplinari per } \\
\text { a l'intercanvi d'idees i per a la reflexió compartida entre totes les especialitats } \\
\text { en les quals es produeix la investigació, el pensament pedagògic i l'acció edu- } \\
\text { cativa. } \\
\text { És una de les poques revistes espanyoles en la categoria **INT2 (impacte inter- } \\
\text { nacional) de l'índex ERIH i per factor d'impacte. Bordón es troba en el primer } \\
\text { quartil d'INREC-S i MIAR. }\end{array}$ & $\begin{array}{c}\text { De } \\
\text { pagament }\end{array}$ & Castellà \\
\hline $\begin{array}{l}\text { 14. Didáctica de las ciencias } \\
\text { experimentales y sociales } \\
\text { http://ojs.uv.es/index.php/dces }\end{array}$ & 0.344 & $\begin{array}{l}\text { DCES va nàixer el } 1989 \text { i és una revista dedicada a la investigació i innovació en } \\
\text { didàctica de la física, la química, la biologia, les ciències de la terra, l'educació } \\
\text { ambiental i sostenibilitat, la promoció i l'educació per a la salut i la didàctica } \\
\text { de la història i de la geografia. } \\
\text { Està inclosa, amb excel·lent valoració, en les bases de dades de l'INRECS, de la } \\
\text { CIRC, del ISOC, del LATINDEX, del DIU, de la REDIDENET i de DIALNET. }\end{array}$ & Lliure & Castellà \\
\hline
\end{tabular}


Taula 3. Exemple IN-RECS (cont.)

\begin{tabular}{|c|c|c|c|c|}
\hline $\begin{array}{l}\text { 15. Revista Electrónica } \\
\text { Complutense de } \\
\text { Investigación en } \\
\text { Educación Musical } \\
\text { https://revistas.ucm.es/index. } \\
\text { php/RECI/ }\end{array}$ & 0.333 & $\begin{array}{l}\text { Aquesta revista inclou informes d'investigació, articles sobre qüestions epis- } \\
\text { temològiques i metodològiques, revisions de llibres sobre investigació, resse- } \\
\text { nyes sobre congressos o seminaris per tal d'aprofundir en la comprensió de } \\
\text { l'aprenentatge i l'ensenyament de la música. } \\
\text { Dirigida a docents d'educació infantil, primària i secundària i a escoles de } \\
\text { música, conservatoris i universitats. }\end{array}$ & Lliure & $\begin{array}{l}\text { Articles en cas- } \\
\text { tellà, portugués } \\
\text { i anglés }\end{array}$ \\
\hline $\begin{array}{l}\text { 16. Revista Internacional } \\
\text { de Medicina y Ciencias } \\
\text { de la Actividad Física y } \\
\text { del Deporte } \\
\text { http://cdeporte.rediris.es/ } \\
\text { revista/revista.html }\end{array}$ & 0.300 & $\begin{array}{l}\text { Revista multidisciplinària, cientificotècnica, entorn de les ciències de l'activi- } \\
\text { tat física i de l'esport. } \\
\text { Va nàixer l'any } 2000 \text { i és de publicació trimestral. }\end{array}$ & Lliure & $\begin{array}{l}\text { Castellà } \\
\text { i anglés }\end{array}$ \\
\hline $\begin{array}{l}\text { 17. Electronic journal of } \\
\text { research in educational } \\
\text { psychology } \\
\text { http://investigacion-psico- } \\
\text { pedagogica.org/revista/new/ } \\
\text { index.php }\end{array}$ & 0.287 & $\begin{array}{l}\text { Fundada el 2003, va nàixer amb vocació de convertir-se en un referent nacio- } \\
\text { nal i internacional de la psicologia i l'educació. Està especialment dirigida tant } \\
\text { a investigadors com a professionals relacionats en aquests àmbits. } \\
\text { Se n'editen tres números a l'any. }\end{array}$ & Lliure & $\begin{array}{l}\text { Castellà } \\
\text { i anglés }\end{array}$ \\
\hline
\end{tabular}




\begin{tabular}{|c|c|c|c|c|}
\hline $\begin{array}{l}\text { 18. Educació i història: } \\
\text { Revista d'història de } \\
\text { l'educació } \\
\text { http://publicacions. } \\
\text { iec.cat/PopulaFitxa. } \\
\text { do?moduleName=revistes_ci } \\
\text { entifiques\&subMod } \\
\text { uleName=darreres_- } \\
\text { novetats\&idColleccio }=199 \#\end{array}$ & 0.271 & $\begin{array}{l}\text { Revista semestral de la Societat d'Història de l'Educació dels Països de Llen- } \\
\text { gua Catalana. } \\
\text { Els temes més habituals que s'aborden són: el pensament pedagògic, les insti- } \\
\text { tucions educatives, els fenòmens de socialització, l'educació informal, la rela- } \\
\text { ció entre política i educació, la història de l'escola, llibres i materials escolars, } \\
\text { associacions juvenils, la història de la infància i els temes referents a l'ense- } \\
\text { nyament històric de l'educació. } \\
\text { Va dirigida als investigadors en història de l'educació. És per això que es distri- } \\
\text { bueix gratuïtament als socis de la Societat d'Història de l'Educació dels Països } \\
\text { de Llengua Catalana. }\end{array}$ & $\begin{array}{c}\text { Gratuïta } \\
\text { per a socis. } \\
\text { Accessible en } \\
\text { línia: http:// } \\
\text { revistes.iec. } \\
\text { cat/index.php/ } \\
\text { EduH }\end{array}$ & Català \\
\hline $\begin{array}{l}\text { 19. Psicología educativa } \\
\text { http://www.copmadrid.org/ } \\
\text { webcopm/resource.do }\end{array}$ & 0.270 & $\begin{array}{l}\text { Revista científica professional i espanyola, de caràcter multidisciplinari, que } \\
\text { promou tant l'aportació teòrica com la investigació experimental i professional } \\
\text { en psicologia i en les professions afins en l'àmbit educatiu. } \\
\text { El seu objectiu és compartir temes d'interés comú quant a processos cognitius, } \\
\text { afectius i culturals en l'adquisició del coneixement, així com en àrees d'inter- } \\
\text { venció i innovació educativa. } \\
\text { Està indexada en Science Direct i Scopus. }\end{array}$ & Lliure & Castellà \\
\hline
\end{tabular}


Taula 3. Exemple IN-RECS (cont.)

\begin{tabular}{|l|l|l|l|}
\hline $\begin{array}{l}\text { 20. ESE: Estudios sobre } \\
\text { educación }\end{array}$ & 0.257 & $\begin{array}{l}\text { Té com a objecte primordial contribuir a la difusió del creixent nombre de } \\
\text { resultats d'investigació originals, tant teòrics com experimentals, que es re- } \\
\text { alitzen a Espanya i en altres països en els diversos àmbits de les ciències de } \\
\text { estudios-sobre-educacion/ } \\
\text { portada-revista }\end{array}$ & $\begin{array}{l}\text { l'educació. } \\
\text { Els articles publicats estan indexats en el Social Science Citation Index de } \\
\text { ThomsonisI. } \\
\text { Cada número s'edita tant en versió impresa com en versió electrònica. A aques- } \\
\text { ta última es pot accedir a través de EBsco, Host Electronic Journal Service. }\end{array}$ \\
\hline
\end{tabular}


Taula 4. Exemple JCR

\begin{tabular}{|l|l|l|c|}
\hline $\begin{array}{l}\text { 1. Review of Educational } \\
\text { Research } \\
\text { http://rer.sagepub.com/ }\end{array}$ & 4.229 & $\begin{array}{l}\text { La revista es va iniciar el 1931, és trimestral i publica crítiques i revisions } \\
\text { sobre investigacions de literatura i educació, incloent-hi conceptualitzacions, } \\
\text { interpretacions i síntesis de la literatura i el treball acadèmic en un camp molt } \\
\text { rellevant per a l'educació i la investigació educativa. }\end{array}$ & $\begin{array}{c}\text { De } \\
\text { pagament }\end{array}$ \\
\hline $\begin{array}{l}\text { 2. Learning and Instruction } \\
\text { http://www.journals.elsevier. } \\
\text { com/learning-and-instruction/ }\end{array}$ & 3.337 & $\begin{array}{l}\text { Revista internacional i multidisciplinària que proporciona una plataforma per } \\
\text { a la publicació de la investigació científica més avançada en àrees d'aprenen- } \\
\text { tatge, desenvolupament, instrucció i ensenyament. }\end{array}$ & $\begin{array}{c}\text { De } \\
\text { pagament }\end{array}$ \\
\hline $\begin{array}{l}\text { 3. American Educational } \\
\text { Research Journal } \\
\text { http://aer.sagepub.com/ }\end{array}$ & 3.104 & $\begin{array}{l}\text { Publica estudis empírics i teòrics i, a més, anàlisis d'educació que constituei- } \\
\text { xen importants contribucions a la comprensió i millora de processos i resultats } \\
\text { educatius. }\end{array}$ & $\begin{array}{c}\text { De } \\
\text { pagament } \\
\text { La secció d'anàlisi institucional i social se centra en temes polítics, culturals, } \\
\text { socials, econòmics i organitzatius en l'educació i l'ensenyament i en l'apre- } \\
\text { nentatge. En la secció de desenvolupament humà s'exploren els processos i els } \\
\text { resultats de l'ensenyament, l'aprenentatge i el desenvolupament humà en tots } \\
\text { els nivells educatius en situacions formals i informals. }\end{array}$ \\
\hline
\end{tabular}




\begin{tabular}{|c|c|c|c|c|}
\hline $\begin{array}{l}\text { 4. Journal of the Learning } \\
\text { Sciences } \\
\text { http://www.tandfonline.com/ } \\
\text { action/authorSubmission?jour } \\
\text { nalCode=hlns\&page=instructi } \\
\text { ons\#.UrsmH_TuKJk }\end{array}$ & 3.036 & $\begin{array}{l}\text { Ofereix un fòrum multidisciplinari per a la presentació de la investigació sobre } \\
\text { l'aprenentatge i l'educació. } \\
\text { Tracta de fomentar noves formes de pensament sobre l'aprenentatge i publicar } \\
\text { articles d'investigació, l'objectiu fonamental dels quals és la comprensió dels } \\
\text { processos, les eines i els contextos, així com els resultats d'aprenentatge en les } \\
\text { seues múltiples formes. } \\
\text { JLS ha estat entre les cinc revistes més citades en educació durant els últims } \\
\text { cinc anys. }\end{array}$ & $\begin{array}{c}\text { De } \\
\text { pagament }\end{array}$ & Anglés \\
\hline $\begin{array}{l}\text { 5. Academy of Management } \\
\text { Learning \& Education } \\
\text { http://aom.org/amle/ }\end{array}$ & 3.000 & $\begin{array}{l}\text { Examina qüestions urgents en els àmbits de l'aprenentatge i l'educació de } \\
\text { gestió mitjançant la presentació de teoria, models, investigació i crítiques que } \\
\text { s'ocupen del procés d'aprenentatge i la pràctica de l'educació de gestió. } \\
\text { Dirigida a acadèmics, educadors, directors i degans de les institucions aca- } \\
\text { dèmiques, així com als professionals de la formació, el desenvolupament i } \\
\text { l'educació empresarial. } \\
\text { Publicada trimestralment al març, juny, setembre i desembre. }\end{array}$ & $\begin{array}{c}\text { De } \\
\text { pagament }\end{array}$ & Anglés \\
\hline $\begin{array}{l}\text { 6. Educational Researcher } \\
\text { http://edr.sagepub.com/ }\end{array}$ & 2.779 & $\begin{array}{l}\text { Publica articles acadèmics que són d'importància general per a la comuni- } \\
\text { tat d'investigadors de l'educació. Aquests procedeixen d'una àmplia gamma } \\
\text { d'àrees d'investigació en educació i disciplines afins. } \\
\text { Publicat nou vegades a l'any, ER pretén fer major investigació programàtica i } \\
\text { nous descobriments de gran importància i àmpliament accessibles. }\end{array}$ & $\begin{array}{c}\text { De } \\
\text { pagament }\end{array}$ & Anglés \\
\hline
\end{tabular}




\begin{tabular}{|c|c|c|c|c|}
\hline $\begin{array}{l}\text { 7. Computers \& Education } \\
\text { http://www.journals.elsevier. } \\
\text { com/computers-and-educa- } \\
\text { tion/ }\end{array}$ & 2.775 & $\begin{array}{l}\text { Fòrum de base tècnica i interdisciplinari que promou l'ús de totes les formes } \\
\text { d'informàtica en àrees d'aplicació social i tecnològica. } \\
\text { Es publiquen contribucions que serveixen de referència per a avaluar l'estat de } \\
\text { l'art actual en aquesta temàtica. }\end{array}$ & $\begin{array}{c}\text { De } \\
\text { pagament }\end{array}$ & Anglés \\
\hline $\begin{array}{l}\text { 8. Educational Research } \\
\text { Review } \\
\text { http://www.journals.elsevier. } \\
\text { com/educational-research- } \\
\text { review/ }\end{array}$ & 2.586 & $\begin{array}{l}\text { Nova revista internacional dirigida a investigadors i a diferents organismes } \\
\text { interessats en la revisió d'estudis de l'educació i l'ensenyament a qualsevol } \\
\text { nivell. } \\
\text { La revista accepta revisions meta-analítiques crítiques, de narrativa i de síntesi. }\end{array}$ & $\begin{array}{l}\text { De paga- } \\
\text { ment. Dispo- } \\
\text { nible l'últim } \\
\text { número } \\
\text { gratuït en: } \\
\text { http://www. } \\
\text { academic } \\
\text { journals.org/ } \\
\text { journal/ERR }\end{array}$ & Anglés \\
\hline $\begin{array}{l}\text { 9. Journal of Research in } \\
\text { Science Teaching } \\
\text { http://onlinelibrary.wiley.com/ } \\
\text { journal/10.1002/(ISSN)1098- } \\
2736\end{array}$ & 2.552 & $\begin{array}{l}\text { És la revista oficial de l'Associació Nacional per a la Recerca en Ensenyament } \\
\text { de les Ciències. } \\
\text { Publica informes dels investigadors d'educació científica i professionals sobre } \\
\text { temes de didàctica de la ciència i la política de l'educació científica. } \\
\text { Inclou també investigacions qualitatives, etnogràfiques i històriques, enques- } \\
\text { tes, estudis de cas, resums d'investigació, revisions crítiques de literatura, co- } \\
\text { mentaris i crítiques, etc. }\end{array}$ & $\begin{array}{c}\text { De } \\
\text { pagament }\end{array}$ & Anglés \\
\hline
\end{tabular}




\begin{tabular}{|c|c|c|c|c|}
\hline $\begin{array}{l}\text { 10. Reading Research } \\
\text { Quarterly } \\
\text { http://onlinelibrary.wiley.com/ } \\
\text { journal/10.1002/(ISSN)1936- } \\
\text { 2722/homepage/ForAuthors. } \\
\mathrm{html}\end{array}$ & 2.382 & $\begin{array}{l}\text { Revista internacional d'investigació. S'hi publiquen investigacions de màxima } \\
\text { qualitat sobre la lectura i l'alfabetització. } \\
\text { La seua missió principal és fomentar les connexions entre els investigadors per } \\
\text { a construir una base de coneixements coherent en la lectura i l'alfabetització } \\
\text { més enllà de fronteres geogràfiques i intel·lectuals. } \\
\text { RRQ es publica en línia i s'imprimeix quatre vegades a l'any: gener, abril, juliol } \\
\text { i octubre. }\end{array}$ & $\begin{array}{l}\text { De } \\
\text { pagament, } \\
\text { alguns } \\
\text { articles } \\
\text { d'accés } \\
\text { lliure }\end{array}$ & Anglés \\
\hline $\begin{array}{l}\text { 11. Science Education } \\
\text { http://onlinelibrary.wiley.com/ } \\
\text { journal/10.1002/(ISSN)1098- } \\
237 \mathrm{X}\end{array}$ & 2.382 & $\begin{array}{l}\text { Publica articles originals sobre les últimes qüestions i tendències que es pro- } \\
\text { dueixen a nivell internacional en el currículum de la ciència, l'ensenyament, } \\
\text { l'aprenentatge, la política i la preparació dels professors de ciències. } \\
\text { Té com objectiu avançar en el coneixement de la ciència, la teoria i la pràctica } \\
\text { de l'educació. }\end{array}$ & $\begin{array}{c}\text { De } \\
\text { pagament }\end{array}$ & Anglés \\
\hline $\begin{array}{l}\text { 12. Early Childhood } \\
\text { Research Quarterly } \\
\text { http://www.journals.elsevier. } \\
\text { com/early-childhood-rese- } \\
\text { arch-quarterly/ }\end{array}$ & 2.275 & $\begin{array}{l}\text { Publica sobretot investigacions empíriques sobre qüestions d'interés per al } \\
\text { desenvolupament de la primera infància i la teoria i la pràctica educatives (des } \\
\text { del naixement fins als } 8 \text { anys d'edat). } \\
\text { És la revista acadèmica afiliada a la National Association for the Education of } \\
\text { Young Children (NAEYC). }\end{array}$ & $\begin{array}{c}\text { De } \\
\text { pagament }\end{array}$ & Anglés \\
\hline $\begin{array}{l}\text { 13. Review of Research } \\
\text { in Education } \\
\text { http://rre.sagepub.com/ }\end{array}$ & 2.111 & $\begin{array}{l}\text { Es va iniciar el } 1973 \text { i proporciona una descripció anual i una anàlisi descripti- } \\
\text { va de temes de literatura d'investigació a través d'assajos crítics. } \\
\text { Promou la discussió i la controvèrsia sobre els problemes d'investigació, a més } \\
\text { de reunir i resumir el treball d'aquest camp. }\end{array}$ & $\begin{array}{c}\text { De } \\
\text { pagament }\end{array}$ & Anglés \\
\hline
\end{tabular}




\begin{tabular}{|c|c|c|c|c|}
\hline $\begin{array}{l}\text { 14. Advances in Health } \\
\text { Sciences Education } \\
\text { http://www.springer.com/ } \\
\text { education+\%26+language/ } \\
\text { journal/10459 }\end{array}$ & 2.061 & $\begin{array}{l}\text { Fòrum per a l'estudi i l'estat de l'art de la investigació en tots els aspectes de } \\
\text { ciències de la salut en educació. Es publiquen estudis empírics, així com dis- } \\
\text { cussions sobre assumptes teòrics i implicacions pràctiques. } \\
\text { L'enfocament principal de la revista és la vinculació de la teoria amb la pràctica, } \\
\text { atorgant importància als papers que té una base teòrica i de metodologia sòlida. }\end{array}$ & $\begin{array}{c}\text { De } \\
\text { pagament }\end{array}$ & Anglés \\
\hline $\begin{array}{l}\text { 15. Internet and Higher } \\
\text { Education } \\
\text { http://www.journals.elsevier. } \\
\text { com/the-internet-and-higher- } \\
\text { education/ }\end{array}$ & 2.013 & $\begin{array}{l}\text { Revista trimestral sobre temes relacionats amb l'aprenentatge en línia, l'ense- } \\
\text { nyament i l'administració d'internet. } \\
\text { La revista és internacional i interdisciplinària i convida les contribucions de tot } \\
\text { el món i de diferents disciplines acadèmiques. } \\
\text { L'abast de la revista és ampli quant a la varietat de temes i tendències. }\end{array}$ & $\begin{array}{c}\text { De } \\
\text { pagament }\end{array}$ & Anglés \\
\hline $\begin{array}{l}\text { 16. Journal of Engineering } \\
\text { Education } \\
\text { http://onlinelibrary.wiley.com/ } \\
\text { journal/10.1002/(ISSN)2168- } \\
9830\end{array}$ & 1.925 & $\begin{array}{l}\text { JEE és una revista internacional publicada trimestralment per la Societat Ame- } \\
\text { ricana per a la Formació d'Enginyers. Es fa amb la col·laboració d'una comu- } \\
\text { nitat global de societats i associacions d'educació d'enginyeria. } \\
\text { Serveix per a difondre i arxivar la investigació acadèmica en l'ensenyament } \\
\text { de l'enginyeria. }\end{array}$ & $\begin{array}{c}\text { De } \\
\text { pagament }\end{array}$ & Anglés \\
\hline $\begin{array}{l}\text { 17. International Journal of } \\
\text { Computer-Supported } \\
\text { Collaborative Learning } \\
\text { http://www.springer.com/ } \\
\text { education+\% } \% 26+\text { language/ } \\
\text { learning+\%26+instruction/ } \\
\text { journal/11412?cm } \\
\text { mmc=sgw-_-ps-_-jour- } \\
\text { nal-_-11412 }\end{array}$ & 1.717 & $\begin{array}{l}\text { Revista professional i acadèmica fundada el } 2006 \text { que aborda els usos de CSCL } \\
\text { en l'educació, els negocis i la societat en general, així com l'impacte psicolò- } \\
\text { gic, social i tecnològic de CSCL en els individus, els grups i la societat. } \\
\text { El principal objectiu de la revista és promoure una comprensió més profunda } \\
\text { de la naturalesa, la teoria i la pràctica dels usos de CSCL. Un focus principal està } \\
\text { en com aprenen les persones en el context d'activitats de col·laboració i com } \\
\text { dissenyar els ajustos tecnològics per a la col·laboració. } \\
\text { La revista proporciona un fòrum per a la comunicació entre experts de dife- } \\
\text { rents disciplines de les ciències de l'aprenentatge. }\end{array}$ & $\begin{array}{c}\text { De } \\
\text { pagament }\end{array}$ & Anglés \\
\hline
\end{tabular}




\begin{tabular}{|c|c|c|c|c|}
\hline $\begin{array}{l}\text { 18. Sociology of Education } \\
\mathrm{http}: / / \text { soe.sagepub.com/ }\end{array}$ & 1.697 & $\begin{array}{l}\text { Publicada trimestralment, proporciona un fòrum per als estudis de la sociolo- } \\
\text { gia de l'educació i el desenvolupament social humà. Publica investigacions } \\
\text { que examinen com les institucions socials i les experiències dels individus, } \\
\text { dins d'aquestes institucions, afecten els processos educatius i de desenvolupa- } \\
\text { ment social. }\end{array}$ & $\begin{array}{c}\mathrm{De} \\
\text { pagament }\end{array}$ & Anglés \\
\hline $\begin{array}{l}\text { 19. British Educational } \\
\text { Research Journal } \\
\text { http://www.tandfonline. } \\
\text { com/toc/cber20/current\#. } \\
\text { Ur9gtvTuKJk }\end{array}$ & 1.660 & $\begin{array}{l}\text { Revista internacional per a la publicació de la investigació educativa de tot el } \\
\text { món. } \\
\text { Parteix d'un enfocament interdisciplinari i inclou informes d'estudis de cas, } \\
\text { experiments, enquestes, discussions de temes conceptuals i metodològics i dels } \\
\text { supòsits subjacents en la investigació educativa, així com ressenyes de llibres. }\end{array}$ & $\begin{array}{c}\text { De } \\
\text { pagament }\end{array}$ & Anglés \\
\hline $\begin{array}{l}\text { 20. Journal of Computer } \\
\text { Assisted Learning } \\
\text { http://onlinelibrary.wiley.com/ } \\
\text { journal/10.1111/(ISSN)1365- } \\
2729\end{array}$ & 1.632 & $\begin{array}{l}\text { Revista internacional que cobreix els usos de les noves tecnologies de la infor- } \\
\text { mació i la comunicació per a recolzar l'aprenentatge i l'intercanvi de coneixe- } \\
\text { ments. } \\
\text { El seu objectiu és proporcionar un mitjà de comunicació entre els investiga- } \\
\text { dors, els professionals i els responsables polítics. JCAL és també una rica font } \\
\text { de material per als estudiants d'investigació en àrees com l'aprenentatge col- } \\
\text { laboratiu, l'enginyeria del coneixement, l'aprenentatge en xarxa, la psicologia } \\
\text { del desenvolupament i l'avaluació. }\end{array}$ & $\begin{array}{c}\text { De } \\
\text { pagament }\end{array}$ & Anglés \\
\hline
\end{tabular}




\section{Capitol 7. \\ Com elaborar un article per a una revista?}

L'article científic permet a l'investigador donar a conéixer els resultats de la seua investigació mitjançant la publicació d'aquesta en revistes especialitzades, i a més constitueix la principal via de difusió per a la comunitat científica. Es tracta d'un text de caràcter acadèmic amb una estructura ben definida. Encara així, existeixen diferents tipus d'articles que permeten a l'investigador abordar la difusió dels seus coneixements des de diferents perspectives.

Entre els principals tipus d'articles científics destaquen els articles d'investigació originals, és a dir, aquells en els quals l'autor presenta noves dades obtingudes a través de la seua recerca i que no han sigut publicades prèviament. A més dels articles d'investigació originals, podem trobar en les revistes científiques tot un seguit d'articles que donen resposta a les diferents necessitats de difusió de la comunitat científica:

- Articles de revisió

- Articles de metanàlisi

- Articles de reflexió o assajos

- Articles sobre propostes didàctiques

- Cartes a l'editor

\subsection{Estructura d'un article científic}

L'estructura i les característiques d'un article venen inicialment marcades per la seua tipologia i pels requisits específics que determina cada revista. Davant tal diversitat, a continuació es desenvoluparà exclusivament l'estructura bàsica que solen tindre els articles d'investigació originals. Per tant, abans de preparar un article, serà necessari conéixer les característiques i els requisits específics de la revista en la qual es pretén publicar-ho.

- Títol. El títol ha de ser capaç de descriure la investigació realitzada. Es tracta d'una frase breu i directa en la qual l'autor/a exposa la problemàtica abordada amb el seu estudi. Cada revista pot establir la seua pròpia normativa sobre aquest apartat, però de forma general es recomana no utilitzar abreviatures ni noms propis. 
- Autors/es. Un article científic el pot escriure un únic investigador o un grup d'investigadors. Per a ser considerat l'autor d'un article, un investigador hi ha d'haver contribuït notablement en el procés d'elaboració. Habitualment, el nombre d'autors que signen un article és reduït (entre 1 i 5), però segons les característiques del treball i de l'àrea de coneixement el nombre es pot ampliar considerablement. Existeix la convenció d'escriure el primer nom complet de l'autor, seguit de la inicial del segon i, finalment, el primer cognom. Els noms dels diferents autors apareixen de forma seqüencial, de manera que el primer signant serà aquell que haja realitzat una major contribució a l'article. Resultaria inadequat incloure com a autora una persona amb una contribució mínima o nul·la a l'article (autoria injustificada), o negar-li crèdit d'autor a una persona responsable d'una part decisiva del contingut intel·lectual del mateix (autoria incompleta). A més d'incloure els noms dels autors, és necessari incloure la filiació de cadascun d'ells, és a dir, la institució a la qual pertany cadascun. Així mateix, resulta necessari establir un dels autors com a responsable de la correspondència. Açò implica que les seues dades de contacte han d'aparéixer clarament identificables perquè qualsevol investigador interessat siga capaç de contactar amb ell.

- Resum. El resum resulta un apartat clau de l'article en el qual se sintetitzen les principals característiques del treball. Segons els requisits establerts per cada revista, el resum hauria d'oscil·lar entre les 250 i les 500 paraules, i hauria de seguir una estructura similar a l'article (ex.: objectiu, metodologia, resultats $i$ conclusions).

- Paraules clau. Constitueixen els termes que descriuen i permeten conéixer la temàtica i els aspectes centrals de l'article. Es tracta de 3 a 5 paraules triades per l'autor i que no haurien d'estar contingudes en el títol. Aquestes paraules, juntament amb el títol, resulten els elements principals per a la indexació de l'article i, per tant, permeten localitzar-lo per part de qualsevol investigador que faça una cerca bibliogràfica utilitzant termes similars.

- Introducció. La introducció constitueix l'apartat en què l'autor ha d'establir el nivell de coneixement actual sobre el problema a resoldre. Ha d'evitar abocar opinions personals o fer un repàs històric. Basant-se en la literatura científica més recent, l'autor ha de ser capaç de focalitzar el problema i destacar l'originalitat i utilitat del seu treball. De forma general, aquest apartat ha de posar de manifest la capacitat de síntesi de l'autor, el qual, a partir d'allò més general, ha de ser capaç de justificar la hipòtesi del seu treball i els objectius plantejats, recolzant-se en les investigacions prèvies amb un major nivell d'afinitat.

- Metodologia. Aquest apartat es focalitza en explicar com s'ha estudiat el problema plantejat a la introducció. L'autor/a ha de descriure, de la forma més precisa possible, el disseny de la investigació i explicar com l'ha portada a terme. En el cas de la investigació educativa, resulta habitual descriure les persones que conformen la mostra, descriure les tècniques i instruments 
utilitzats per a arreplegar la informació, i finalment detallar el procés seguit per a l'anàlisi de les dades i el programari utilitzat. Així mateix, han d'especificar-s'hi les normes ètiques seguides per al desenvolupament del treball i referenciar el comitè ètic que va aprovar-ne la realització. Es tracta d'un apartat exclusivament descriptiu, en el qual s'han d'ometre opinions i judicis de valor. Així mateix, per tractar de recolzar la idoneïtat de la metodologia emprada, és possible incloure-hi referències a treballs realitzats per altres investigadors.

- Resultats. L'apartat de resultats constitueix l'eix vertebrador de l'article. Es tracta d'un apartat descriptiu sobre les troballes més rellevants de la investigació. La seua redacció ha de ser totalment objectiva, absent d'interpretacions per part de l'autor, i amb una estructura lògica sobre la base dels objectius plantejats i la metodologia emprada. La part narrativa dels resultats sol anar acompanyada de taules i/o figures que en faciliten la comprensió. Igualment, es poden incloure imatges, dibuixos, diagrames, o qualsevol altre element que recolze el text. El disseny d'aquests elements, així com les seues principals característiques, sol estar establert per les directrius específiques de cada revista, cercant-se de forma general la simplicitat i una fàcil interpretació visual.

- Discussió. La discussió constitueix la part més creativa de l'article, on l'autor destaca i interpreta els resultats principals del seu estudi. Es tracta d'analitzar els resultats més rellevants sobre la base dels objectius de l'estudi i relacionar-los amb la literatura científica prèvia, tot destacant els avenços assolits. Aquest apartat sol començar destacant breument les principals troballes de l'estudi. A continuació, es plantegen les diferents interpretacions de forma crítica, s'analitzen les fortaleses i febleses de l'estudi i es plantegen les conclusions més rellevants. Finalment, es destaquen les aplicacions pràctiques de l'estudi i s'ofereixen recomanacions per a futures investigacions.

- Agraïments. Aquest apartat constitueix una mostra d'agraïment formal a totes aquelles persones $\mathrm{i} / \mathrm{o}$ institucions que d'una forma o altra han contribuiit en l'article però que no poden ser considerades autores intel·lectuals del mateix. Habitualment s'hi inclouen les institucions que hi han col-laborat econòmicament, bé cedint infraestructures, o bé aportant materials, gestionant el desenvolupament de l'estudi, etc. També s'hi solen incloure les persones que han contribuït en el desenvolupament de l'estudi i/o a la confecció de l'article, sense arribar a poder ser considerades autores.

- Referències. Les referències de l'article han d'incloure exclusivament els treballs científics citats en el cos del mateix. Habitualment es tracta d'articles científics i llibres, encara que, segons les característiques del treball dut a terme, s'hi poden incloure un altre tipus de documents de difusió (ex.: comunicacions a congressos, tesis doctorals, etc.). Cada revista estableix el seu propi format per a citar les referències bibliogràfiques, encara que de forma habitual, en la investigació educativa, sol utilitzar-se el format establert per 
la American Psychological Association (http://apastyle.org/). Aquest apartat pot realitzar-se de forma manual, però existeixen diversos programes informàtics, denominats gestors bibliogràfics, que permeten adaptar el format de les referències a les demandes de cada revista sense necessitat de modificar cada cita de forma individual i/o manual. Encara que aquest aspecte queda totalment fora dels objectius d'aquest manual, entre els gestors bibliogràfics més habituals s'hi poden destacar els següents:

- Endnote: http://endnote.com/

- Refworks: https://www.refworks.com/es/

- Zotero: https://www.zotero.org/

- Mendeley: http://www.mendeley.com/

\subsection{Passos a seguir per a la confecció d'un article científic}

Escriure un article científic no és una tasca senzilla, més aviat podem dir que es tracta d'un complex procés que requereix un alt grau d'organització i atenció. Cada autor té la seua pròpia metodologia de treball a l'hora d'abordar aquesta tasca, no obstant açò, tots i totes coincideixen a apuntar que és un procés creatiu i en constant evolució, que requereix de diverses competències que s'adquireixen i s'implementen com a fruit de l'experiència.

Encara que es pot afirmar que existeixen moltes maneres de procedir a l'hora d'elaborar un article científic, a continuació s'estableix l'ordre d'elaboració més adequat per al seu desenvolupament:

- Triar la revista i analitzar amb detall la guia de publicació per a autors/es.

- Desenvolupar la metodologia emprada en l'estudi.

- Descriure els resultats de l'estudi.

- Discutir els resultats i establir les principals conclusions de l'estudi.

- Desenvolupar la introducció.

- Elaborar l'apartat de referències bibliogràfiques.

- Escriure el resum de l'article.

- Dissenyar el títol de l'article.

- Comprovar que la versió final de l'article s'adeqüe als requisits establerts per la revista a la qual s'enviarà per a la revisió. 


\section{Capítol 8. \\ Com elaborar \\ una comunicació per a \\ un congrés?}

La manera de transferir el coneixement de manera ràpida $i$ amb la possibilitat d'establir un diàleg directe amb l'interlocutor que està explicant la seua investigació és una comunicació en un congrés.

Un congrés és una reunió o conferència, generalment periòdica, en què els membres d'una associació, cos, organisme, professió, col·lectiu, etc., es reuneixen per a debatre qüestions prèviament fixades de qualsevol camp científic. Els professionals amb interessos comuns en els temes proposats en el congrés comparteixen els seus coneixements i s'enriqueixen de les aportacions de la resta d'una forma personal, directa i amb la possibilitat de preguntar, rebatre o cooperar in situ. El congrés és beneficiós perquè aporta aquesta dimensió d'instantaneïtat que no pot proporcionar el canal escrit, caracteritzat per una comunicació unidireccional, com és el cas d'un article d'investigació o un llibre. Entre els diàlegs que sorgeixen en els debats $i$ en els moments distesos, es pot arribar a teixir una xarxa de contactes difícil de fer en altres fòrums.

Generalment, per a poder anomenar-lo congrés (o trobada o simposi), ha de tindre una duració de 3 a 5 dies com a mínim. En cas contrari, podria catalogar-se de conferència, jornada, convenció o assemblea, entre d'altres. Els congressos poden ser nacionals o internacionals, segons l'abast territorial que presenten les persones implicades, i es vertebren pels anomenats comitès del congrés, dels quals existeixen dos tipus:

- Comitè organitzador: és el grup de persones que s'encarrega de cercar el lloc, coordinar la informació que es facilita als assistents, gestionar les inscripcions, organitzar el cronograma, les visites, la restauració, la retolació de les sales, la certificació, la promoció i la difusió de l'esdeveniment, etc. En definitiva, s'encarrega de la gestió del congrés en totes les seues vessants. En ocasions es pot delegar part d'aquesta gestió a empreses que es dediquen a organitzar esdeveniments, però sempre hi ha una part que haurà de gestionar el personal proper al congrés.

- Comitè cientific: vetlla perquè el congrés siga veritablement científic i, entre altres tasques de tipus acadèmic, han de revisar totes les actes de les comu- 
nicacions per a observar que s'adeqüen al tema del congrés i que tenen el rigor que se n'espera. Són personalitats importants amb una trajectòria en la temàtica del congrés i amb un criteri contrastat en els seus currículums.

Podem establir uns objectius a acomplir en un congrés. Òbviament, aquests són genèrics i ajustables a les particularitats que cadascun puga presentar, però poden resultar orientatius:

- Aprofundir i intercanviar punts de vista científics, teòrics i pràctics des de les àrees del coneixement corresponents.

- Contribuir a l'enriquiment científic i actual dels professionals, científics i investigadors en les àrees temàtiques del congrés.

- Reflexionar sobre les àrees concretes de les temàtiques propostes en les taules de debat.

- Aportar solucions, reflexionar, incrementar, estimular i divulgar el desenvolupament de la ciència i els coneixements relacionats amb la temàtica del congrés.

- Estimular i recolzar la investigació en diverses branques del coneixement a què el congrés faça menció. Difondre i publicar els estudis d'importància.

- Proposar solucions científiques i propostes d'intervenció adequades a les problemàtiques plantejades.

- Promoure, agrupar i mantindre l'intercanvi científic i professional entre investigadors, professionals $\mathrm{o} \mathrm{col} \cdot$ lectius interessats en les àrees del congrés $\mathrm{i}$ en àrees afins, a fi de contrastar idees sobre investigacions significatives de les àrees del congrés.

Respecte de l'estructura del congrés, realment no n'hi ha cap que siga fixa. Aquesta varia en funció dels objectius que propose tant el comitè científic com l'organitzador, però habitualment s'hi troben:

- Activitats plenàries. Es tracta de conferències, generalment d'alguna personalitat o autoritat en el tema. En l'horari o cronograma no s'estableix res més en aquest moment perquè els participants puguen acudir sense cap inconvenient. La durada pot ser fins a 90 minuts i habitualment hi ha possibilitat de fer preguntes al ponent.

- Sessions paral·leles. Es desenvolupen en diverses sales a la mateixa hora i en les quals se celebren les comunicacions orals. Aquestes solen ser curtes, d'uns 10 o 15 minuts, i les preguntes poden realitzar-se després de cada presentació o en un temps dedicat al final de la intervenció on, a manera de taula redona, s'estableix un diàleg entre tots els ponents i les preguntes que es poden realitzar per part dels assistents.

- Sessió pòster. En aquest tipus de sessió es pengen uns pòsters per part dels autors/es i aquests romanen al costat d'ells. Els diferents pòsters resumeixen i presenten de manera gràfica la investigació realitzada per les persones que opten per aquesta modalitat. Sense cap ordre especial, els assistents al con- 
grés passegen per l'espai on es troben exposats i s'acosten a aquells estudis que els interessen, establint un diàleg amb els autors, si es considera necessari. Però, a més, poden estar exposats tot el temps que dure l'esdeveniment. Açò sí, sense la presència constant dels autors, ja que açò només es reserva a la sessió pòster establida en l'horari.

- Activitats de taller. Si es considera necessari, per la temàtica del congrés, es pot organitzar alguna activitat de caràcter pràctic en la qual es puga experimentar de manera directa la investigació dels ponents. Per a això s'estableix un altre escenari que habitualment s'anomena taller. En ells es posa en pràctica alguna temàtica concreta $\mathrm{i}$ es pot ajudar de suport informàtic $\mathrm{o}$ de qualsevol altra índole.

- Activitats acadèmiques/culturals com exposicions, visionat de vídeos o llocs destinats a publicitar llibres o materials relacionats amb el congrés.

- Activitats lúdiques i d'oci com visites turístiques a l'entorn del lloc de celebració del congrés, sopars de gala, cafès o qualsevol acte de gaudi per als assistents.

Una vegada introduït, de manera molt esquemàtica, què és un congrés, ens ocuparem del títol de l'apartat i de com elaborar una comunicació per a un congrés.

Segons les característiques de la investigació, es triarà bé la comunicació oral, o bé el pòster per a presentar-la en un congrés. Vegem quines particularitats té cadascuna d'aquestes modalitats voluntàries de transferir ciència:

\section{a) Comunicació oral}

Quan una persona interessada en el tema del congrés considera que pot aportar alguna investigació original $\mathrm{i}$, per tant, transferir ciència, pot optar pel format de comunicació oral. Com s'ha esmentat, habitualment són sessions paral·leles, açò vol dir que sol haver-ne diverses celebrant-se alhora i són de temps curt (entre 10 i 15 minuts, més el temps dedicat a les preguntes o el debat).

Prèviament a la celebració del congrés, els participants envien, amb mesos d'antelació, una acta de comunicació. Aquest document no és més que la comunicació que la persona investigadora pretén realitzar, però per escrit. Eixe document és el que avalua el comitè científic i n'emet l'acceptació o el rebuig; aquesta resolució permetrà o no que es realitze la comunicació.

Per a la redacció de l'acta de la comunicació, el comitè organitzador dóna les indicacions de format (tipus de lletra, grandària, espaiat, etc.) perquè després es publiquen i així es facilita la tasca de maquetació. Dins d'aquest mateix format s'estableix el nombre màxim de paraules que haurà de contindre la comunicació, la qual haurà d'incloure la següent informació: 
Títol. Ha d'identificar i reflectir amb exactitud el tema del treball, estudi o experiència. Ha de ser específic, concís i evitar les abreviatures, sigles i acrònims, així com l'ús d'argot i de paraules o expressions supèrflues.

Autor/s. Membres que han participat activament en l'estudi, treball o experiència i assumeixen la responsabilitat del contingut intel·lectual del treball. En aquest sentit, convé tindre en compte que pot incloure's un apartat d'agraïments en el qual poden esmentar-se altres persones que hagen participat en el treball, però que no poden considerar-se autores.

Dades d'identificació del/s autor/s, també conegut com a filiació. S'hi ha d'incloure el nom del departament i del centre on treballen els autors, així com la ciutat i el país. No sol ser freqüent la inclusió de l'adreça postal concreta, però habitualment sí que s'inclou l'adreça de correu electrònic per si algú desitja posar-se en contacte amb ells.

Resum. Sol ser obligatori en la llengua de la comunicació i en anglés.

Paraules clau. Seran les paraules que s'inclouran en els motors de cerca de temes concrets en les bases de dades institucionals i científiques. Poden ser frases curtes.

Introducció. Ha de ser curta. Serveix per a familiaritzar el lector amb el tema. Els aspectes que ha de contemplar són: antecedents, revisió del tema (molt curta), importància teòrica o pràctica del tema, hipòtesi, objectius del treball, definicions, etc.

Antecedents. Normalment, ací es troba l'estat de la qüestió. Té la doble finalitat d'aproximar l'investigador a tot el que s'ha investigat sobre el tema fins a l'actualitat i, per tant, preparar-lo per a aportar novetat; per als lectors, serveix per a situar-los en el marc de referència de la investigació que se'ls presenta.

Objectius. Han de ser clars i concisos, que fiten la investigació i indiquen i anticipen tot el procés d'aquesta. Han d'estar íntimament relacionats amb la hipòtesi o les preguntes que es plantegen i que suposadament seran corroborades amb la investigació.

Procedència de dades. S'han d'explicar les característiques de la mostra que s'utilitza per a dur a terme la investigació amb el major detall possible.

Metodologia. Ha de descriure què es farà per a obtindre, recollir i analitzar les dades, és a dir, és el disseny de l'estudi: com es va durà a terme, si tindrà diferents fases, quines variables es consideraran i com s'analitzaran les dades (anàlisi estadística, etc.).

Resultats obtinguts. S'inclourà un resum dels resultats, una vegada analitzats, tant si la hipòtesi o les preguntes que formulàvem s'han pogut provar com si 
no ha sigut així. Se seleccionaran els resultats més rellevants i que estiguen més relacionats amb l'objectiu de l'estudi. Es procurarà evitar textos massa llargs, amb massa valors, índexs o percentatges. L'ús de taules i figures en aquest apartat és molt útil.

Conclusions. També pot incloure's una petita discussió dels resultats, suggeriments, recomanacions, etc. En aquest apartat, i segons els autors que se citen en l'estat de la qüestió, es pot establir un diàleg fictici amb ells per a aportar noves reflexions.

Futures investigacions. S'exposarà de manera molt esquemàtica per on pot discórrer la investigació com a conseqüència del que s'ha fet.

En la primera pàgina de l'acta de la comunicació, habitualment, s'inclou el títol, el nom dels autors i la filiació, és a dir, la universitat o organisme de procedència, juntament amb la localització (correu electrònic) de cadascun d'ells, a més del resum i les paraules clau.

En les pàgines següents ha d'aparéixer el cos del que es vol transmetre, d'acord amb les recomanacions d'estil que el mateix congrés especifica en les orientacions de format.

\section{b) Pòster científic}

La mateixa investigació que puga presentar-se en un congrés amb comunicació oral, podrà ser presentada amb un pòster, que no és més que un resum gràfic que permet difondre els resultats obtinguts d'un treball científic, tecnològic o professional. El pòster constitueix un tipus de comunicació amb un potencial molt gran. Possibilita la transmissió concisa, clara i permanent (mentre dura la reunió o congrés) del seu contingut, sense la fugacitat que imposa una comunicació oral. D'aquesta manera, es pot analitzar amb deteniment per part dels assistents a una velocitat que s'ajuste a les seues capacitats i interessos i possibilita l'objectiu últim de tota comunicació en un congrés: la transmissió d'un missatge per part de l'autor i la seua captació per part dels altres. A més, la possibilitat d'entaular una comunicació directa amb l'autoria del pòster permet el comentari del seu contingut, la discussió ordenada, assossegada i tranquil·la, l'intercanvi d'opinions, etc.

Almenys un dels autors haurà d'estar present durant l'exposició per tal d'explicar i debatre el contingut amb el públic present.

El pòster s'elabora per a ser vist, llegit i comentat. Els continguts del pòster no tenen per què ser de diferent envergadura científica que la comunicació. Simplement, els autors trien un altre format de transferir el coneixement que han generat.

De la mateixa forma que en la comunicació, l'opció de pòster inclou enviar prèviament una acta del que es vol expressar, i el format serà similar al que s'indicava per a l'acta de la comunicació, amb els mateixos apartats. 
En general, en la realització dels pòsters s'intentarà:

- Captar la imatge visual, brindant major flexibilitat per a les explicacions.

- Equilibrar text i il·lustracions.

- Tindre comunicació immediata amb la imatge.

- Tindre la capacitat de síntesi necessària per a transmetre molt en poc espai.

Les recomanacions i mesures del pòster depenen del congrés, encara que com a referència podem prendre la següent:

- Font: Arial o Helvética (negreta).

- Mida: 36 punts (visibilitat a 1,5 o 2 metres).

A continuació presentem dos exemples que il·lustren el que acabem d'exposar:

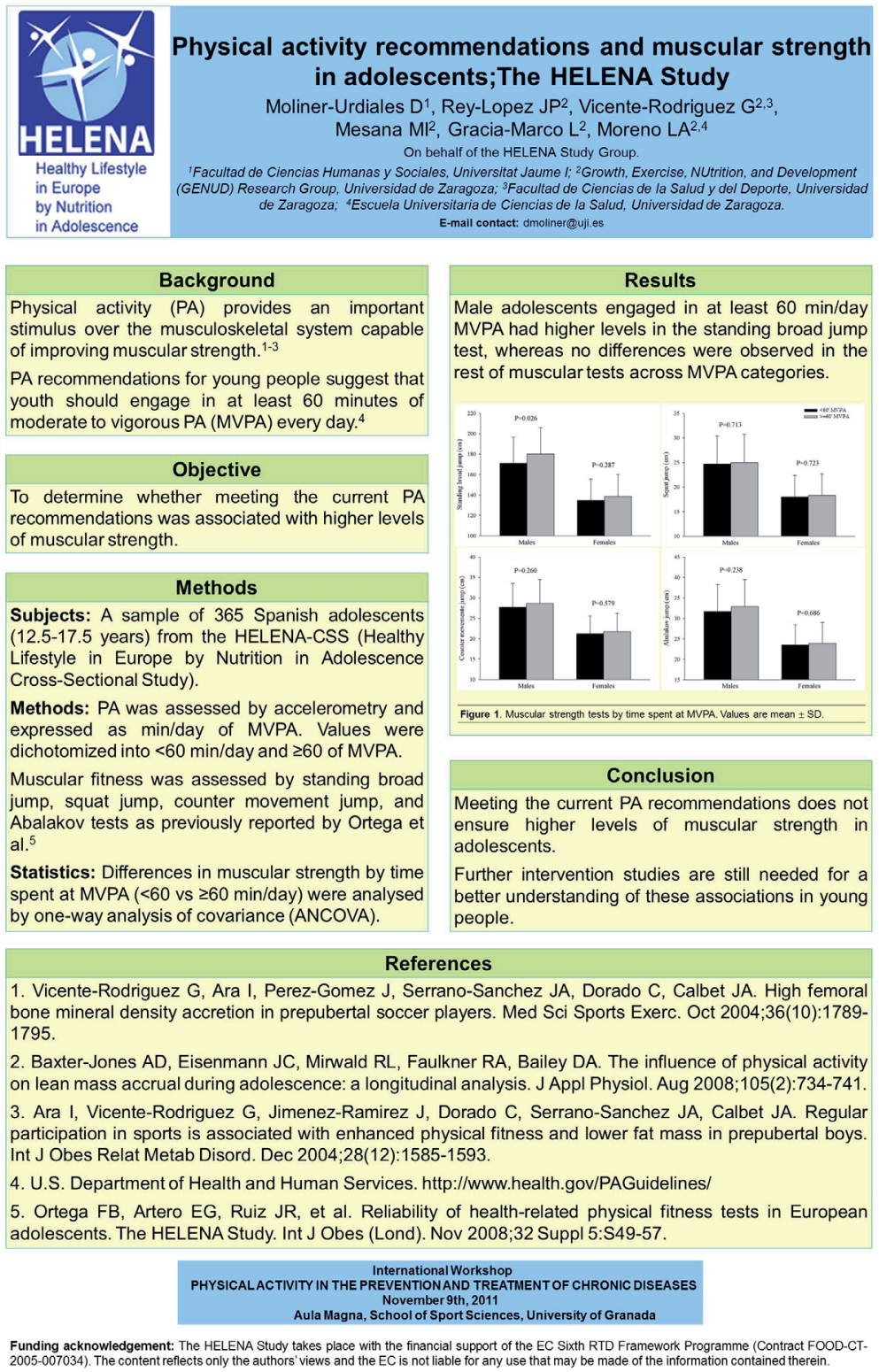

Figura 2. Representació de pòster I 
The importance of traditional songs for the preservation and dissemination of different languages

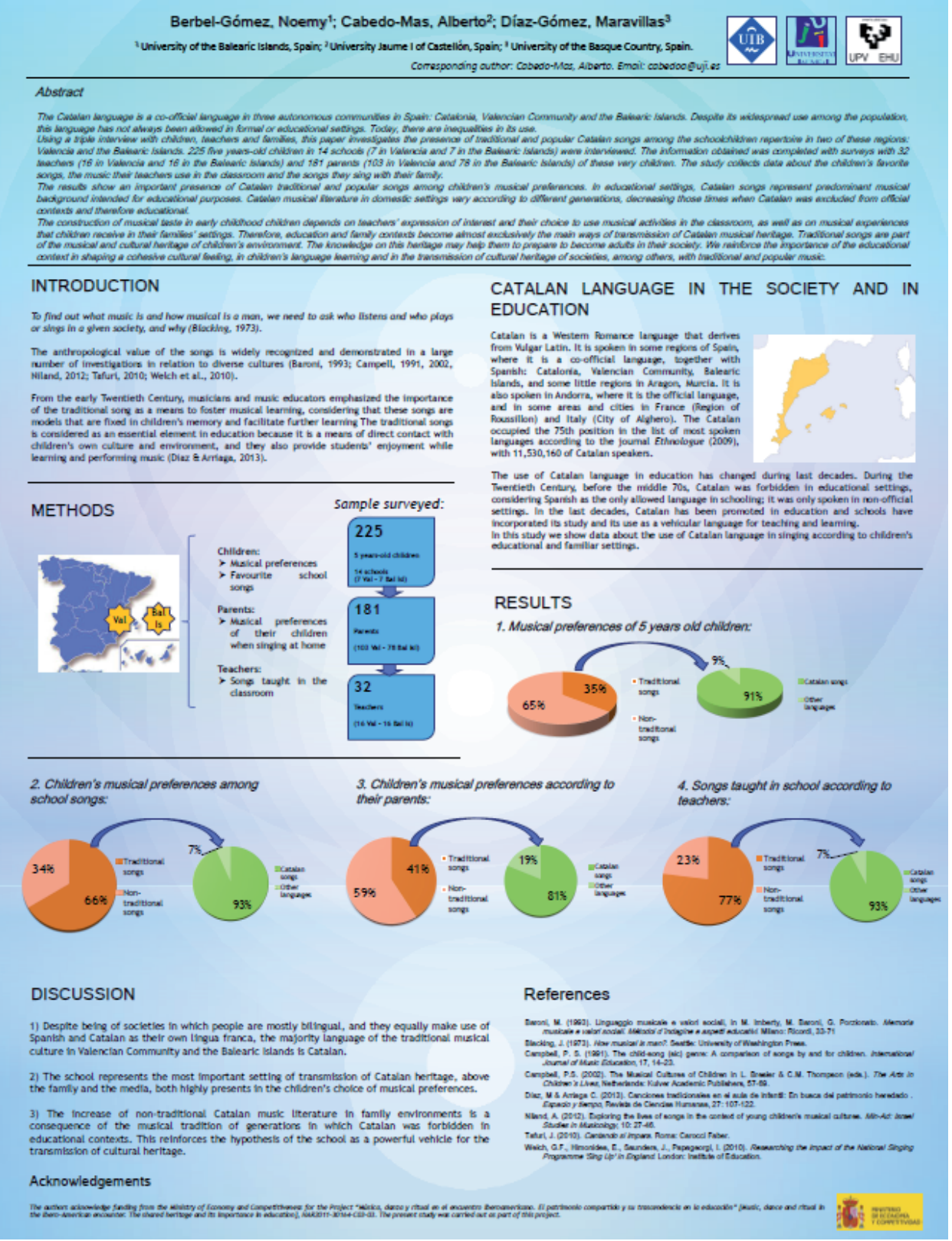

Figura 3. Representació de pòster II 


\section{Bibliografia}

Albert, M. J. (2006): La investigación educativa. Claves teóricas, Mc Graw Hill, Madrid.

Arnal, J.; Rincón, D. i LATORRe, A. (1994): Investigación educativa. Fundamentos $y$ metodologías, Labor, Barcelona.

Buendía, L.; Colàs, P. i Hernández, F. (1998): Métodos de investigación en Psicopedagogía, McGraw Hill, Madrid.

Castells, M. (1996): La era de la información. Economía, sociedad y cultura, vol. 1, Siglo XXI, México.

DAY, R. A. (1988): How to Write \& Publish a Scientific Paper, Editorial Oryx Press, EUA.

DanhKe, G. L. (1989): «Investigación y comunicación», en Fernández-Collado, C. i Danhke, G. L. (coord.): La comunicación humana: Ciencia Social, pp. 385454, McGraw Hill, México.

DíAz, M. (2010): «Metodologías y líneas actuales de investigación en torno a la enseñanza y el aprendizaje musical en educación secundaria. ¿Podemos formarnos para ser investigadores?», en GIRÁLDEZ, A. (coord.): Música. Investigación, innovación y buenas prácticas, pp. 133-156, Graó, Barcelona.

HeRnández Pina, F. (1995): Bases metodológicas de la investigación educativa I. Fundamentos, PPU-DM, Barcelona.

Hernández, R.; Fernández, C. i Baptista, P. (2003): Metodología de la Investigación, McGraw Hill, México.

Kerlinger, F. N. (1985): Investigación del Comportamiento, Interamericana, México.

Martínez, R. A. (2007): La investigación en la práctica educativa: Guía metodológica de investigación para el diagnóstico y evaluación en los centros docentes, MEC, Madrid.

Ponce de LeÓn, L. i LAGO, P. (2014): La música en el mundo académico y profesional, Editorial CCS, Madrid.

SABARIEGO, M. (2004): «La investigación educativa: génesis, evolución y características», en BISQUERRA, R.: Metodología de la investigación educativa, La Muralla, Madrid.

- (2004): «Metodología de la investigación educativa», en BISQUERRA, R.: Metodología de la investigación educativa, La Muralla, Madrid. 